\title{
FIRES IN NATURE: A REVIEW OF THE CHALLENGES FOR WILD ANIMALS
}

\author{
Jara GutiÉRreZ ${ }^{1,2}$ AND Francisco JaVIER De MigueL ${ }^{1}$ \\ ${ }^{1}$ Department of Biology of the Autonomous University of Madrid, Darwin 2, 28049 Madrid, Spain; \\ (+34) 914978286; Fax (+34) 914978344 \\ ${ }^{2}$ Corresponding author: jara.gutierrez@vet.unipi.it
}

\begin{abstract}
.
Animals living in the wild are exposed to numerous challenges, such as fires. Depending on the characteristics of fire, habitat and taxa affected, fires can cause pain, negative experiences, suffering, and death in individual animals. The impacts of fire have been studied in different branches of ecology, but studies of its effects on the welfare of individual animals remain scarce. The current review aims to synthesize a sample of relevant aspects regarding fire's negative effects on wild animals. We mainly focus on the immediate impacts of fire on individuals. How animals respond to fire depends on many factors including their life history, evolutionary adaptations to fire, and individual stress coping styles, in addition to the characteristics of the fire.

The fundamentals of carrying out future work for animal rescue and prevention of animal harms in fires were also explored. Fires may increase the risk of injury, disease, stress, and mortality for animals living in the wild. Although animal taxa differ significantly from each other, a wide variety of vertebrate species (and perhaps some invertebrates) are capable of experiencing both physical and emotional pain, engaging in substantive relationships, and executing cognitively complex tasks. The consequences of fires can involve suffering, psychological damage, negative experiences, discomfort and pain, and long-term detrimental consequences.

Wild animals can benefit from effective rescue, rehabilitation, and release during fires, and post-release monitoring must accurately evaluate their outcome success. The resulting information can be used to educate veterinarians, rehabilitators, and the public in the prevention of the poor welfare and deaths of as many animals as possible in future fire events, which ultimately benefits animal welfare. This review provides a better understanding of how fire compromises animal welfare, providing an example of how to use the knowledge gathered in animal ecology to examine the welfare of wild animals. It can help raise concern for the situation of wild animals as individuals, and to develop the field of welfare biology, by identifying promising future lines of research.
\end{abstract}

Key words: wild animals, animal welfare, animal harms, animal suffering, fires

\section{INTRODUCTION}

In the coming years, wildfires will burn larger areas (Doerr and Santín 2016; Westerling 2016; Rodrigues et al. 2020), and become more frequent and intense (Cochrane and Barber 2009; Flannigan et al. 2009; Jolly et al. 2015), partly as a result of global increases in invasive grasses (D'Antonio and Vitousek 1992), as well as the impact of climate change on fire regimes (Keeley and Syphard 2016; Parks et al. 2016; Michetti and Pinar 2019; Turco et al. 2019; Krikken et al. 2019). Although approximately 4\% of the earth's surface is burned per year (Randerson et al. 2012), most attention is paid to fires which impact humans (Yell 2010).

The characteristics and environmental context of fires, together with life-history differences between species, determine the degree of harm to animals (Whelan et al. 2002; Geary et al. 2019). While exten- sive research has been done on the ecological consequences of fires (Kauffman 2004; Keeley et al. 2005; Andersen et al. 2005; Parr and Andersen 2006; Claridge et al. 2009), the animal welfare impact has not been extensively studied, and has mainly focused on domesticated and companion animals (Irvine 2007; Edmonds and Cutter 2008), because of affection (Heath et al. 2000) or economic interest (Fayt et al. 2005). Recently, a review of existing knowledge on fire management concluded that further investigation about species responses, including examination of occupancy, life history, dispersal, demographics and behavioural responses (Driscoll et al. 2010; Conner et al. 2011; Stawski et al. 2015b; Day 2017) is needed.

Fires have been found to affect the distribution, abundance, and genetic diversity of populations, as they are life-threatening (Kauffman 2004; Yoder 
2004; Turner 2010; Banks et al. 2013; Griffiths and Brook 2014). Both anthropogenic and natural fires, including local deliberate uses for hunting (Bouaket 1999; Daltry and Momberg 2000), may harm animals (Karki 2002). In fact, as a result of Australian mega-fires, very recent studies in ecology have been carried out on the effects on wild Australian fauna (Wintle et al. 2020).

Scientific evidence has established that some animal species have the ability to experience negative psychological stress, suffering, or even chronic stress, due to their cognitive development (DeGrazia and Rowan 1991; Duncan and Petherick 1991; Sherwin 2001; Griffin and Speck 2004). For this reason, it is expected that some taxa perceive fires as stressful events, and consequently trigger physiological and behavioural responses as an evolutionary adaptation to survival (McEwen 2005). While a state of stress can allow glucocorticoids to mobilize energy to positively modify behaviour (Korte et al. 1993; Lee et al. 2015), excessive amounts of perceived stress can lead to negative physiological and psychological consequences for the individual (Anderson 1998), such as fear, anxiety, despair and disorientation, and increased risk of death. The most immediate effects of fire on individual animals include risk of injury and death during flight to unburned areas (Whelan et al. 2002), and second order effects include starvation, dehydration, predation and migration (Silveira et al. 1999a; Whelan et al. 2002).

Numerous studies have evaluated post-disturbance population recovery patterns and processes (Smith and Lyon 2000; Griffiths et al. 2015; Davies et al. 2016; Banks et al. 2017). However, there is a lack of studies on the immediate experienced damage and short-term responses of wild animals during fires (Vernes 2000; Smith and Lyon 2000; Bury et al. 2002; Penn et al. 2003; Banks et al. 2017), including physiological and behavioural adaptations (Stawski et al. 2015b).

\section{Aims And Methodology}

The current review aims to summarize the main negative effects of fires on wild animals on an immediate timescale (from seconds or minutes to several days). The main objective of this work is to gather the essential knowledge for an updated understanding of the threats and poor welfare experienced by wild animals as a result of fires.

The fundamentals for further investigation and promising future lines of research related to the sub- ject are proposed. In the same way, the design of future damage harm prevention and animal rescue protocols are laid out. In summary, the eventual objective is the growth of welfare biology, both in its practical and theoretical perspective, along with the identification of promising future lines of research related to the subject.

The methodology of the present study consists of the evaluation of the most relevant scientific articles and reviews related to the main significant negative effects of fires on animals living in the wild. The search criteria prioritized those scientific articles that evaluated fire effects from the perspective of the individual. We focused our search on articles published in the last two decades. All the selected literature was read by a first observer, and reviewed posterior by the rest of the authors.

The bibliographic search process excluded research only focused on the effect of fire in humans, plant communities and fungi. Scientific articles about long-term fire effects on animals, or positive effects of fires on biodiversity were not of high interest to this review. Nonetheless, we would like to mention that the text includes a short summary of the importance of fire and its potential positive effects on the habitat.

\section{RESULTS}

\section{Injuries and mortality}

Physical damage like burns to the face and limbs are quite common for animals after fires (Rethorst et al. 2018). Rescue actions should include veterinary check-ups assessing burns and other damages incurred from smoke poisoning and traumatic injuries. Research on pathophysiology and burns treatment in animals has generated sustained interest over the past few decades. The first barrier of the animal's body is the skin. Burned skin traps heat inside, spreading the burn to the subcutaneous layer. Initial treatment in mammals often consists of warm water washes to stop the 'microwave' effect and remove traces of soot and plant material(Fowler 2010). The infusion of saline solution and the injection of different drugs are common in the treatment of burns during the first days in rescued animals. Ointments such as silver sulphadiazine and chlorhexidine bandage are also used on burnt skin (Prasad et al. 2016).

The first assessment of burns includes a study of the depth, extent and location (Fowler 2010): (1) most superficial burns (which can generate bleeding 
and tissue damage) are more painful than thick burns (which cause severe skin damage, and a loss of hair, nerves and blood vessels), (2) burns of more than $50 \%$ of the body surface have only the prognosis of death or euthanasia; and (3) wounds located near the joints can lead to scarring that prevents movement and feeding, as occur in arboreal animals as koala (Phascolarctos cinereus) . Nail damage can make it difficult for some mammals to climb, feed, escape, fight, and breed. Injuries located on facial structures can hinder functions such as chewing (Fowler 2010).

Rehabilitation is complicated if the animal suffers from long-term stress. For example, stress syndrome is common in koalas, which easily lose their appetite. Lack of food intake can lead to dehydration and can delay or prevent wound healing. If appropriate, the use of analgesic and anxiolytic drugs may minimize the pain and stress (Kirkwood and Sainsbury 1996). Although some research has been done on survival in rehabilitated koalas versus uninjured individuals (Lunney et al. 2004a), further research on the relationship between fire-related injuries and physical condition or premature mortality is still needed (Ernst et al. 1999; Engstrom 2010), as well as replication of studies in other affected taxa. For instance, koalas initially require intensive care and continuous dressing changes, often accompanied by sedation or general anaesthesia (Fowler 2010). Then, they go to moderate-intensity care in small groups in which they are frequently observed. They finally finish their rehabilitation in wide enclosures in which individuals can express their natural behaviours and develop strength.

Collisions with vehicles also increase as animals fleeing from fire, usually disoriented (Quinn 1979). Intensive care of animals often includes wounds from vehicle collisions that can generate soft tissue and skeletal injuries, mainly affecting the extremities, as reported for New Zealand pigeons (Hemiphaga novaeseelandiae) (Cousins et al. 2012).

Most animals die from asphyxiation during fires (Lawrence 1966), while many more are burnt alive and killed(e.g. deer in Australia;Forsyth et al. 2012). Breathlessness is a negative experience in terms of animal welfare that may involve respiratory effort, chest tightness, and air hunger, the latter being reported to be the most unpleasant (Beausoleil and Mellor 2015).

Although some animals can maintain their body temperature by evaporative cooling (King and Farner 1961), such mechanisms become impossible when water vapour pressure and temperature exceed lethal limits, so deaths from heat damage can occur (Kozlowski 1974). Direct animal mortality from fires has been reviewed (Koprowski et al. 2006) and fire has been reported to induce mortality in mammals, birds, insects, fish, reptiles and amphibians. The risk of mortality depends on characteristics of the species such as mobility (Peres 1999; Silveira et al. 1999a; Barlow and Peres 2004), shelter use (Williams et al. 2010), dietary flexibility (Isaac et al. 2008; Banks et al. 2011b), body size (Cardillo 2003; Griffiths and Brook 2014), etc.

Regarding mammals, while a general decline in population abundance was reported for small mammal species following fire (Keith and Surrendi 1971; Erwin and Stasiak 1979; Geluso and Bragg 1986; Kaufman et al. 1988; Simons 1989; Friend 1993; Fisher and Wilkinson 2005; Banks et al. 2011a; Banks et al. 2017), larger mammals appear to be less prone to mortality due to their increased ability to flee from affected areas (Cardillo 2003; Griffiths and Brook 2014), although at least 10 species of large mammals also exhibited increases in fire-related mortality (Brynard 1972; Gasaway et al. 1989; O1iver et al. 1997; Peres 1999; Silveira et al. 1999b; Barlow and Peres 2004; Williams et al. 2010; Griffiths and Brook 2014).

As for birds, individuals that fly at lower altitudes have been reported to die from smoke inhalation or exhaustion (Campbell 2016). Feeding, cover and nesting habitat changes can negatively impact cavity-nesting populations (Erwin and Stasiak 1979; Horton and Mannan 1988; Lnìons et al. 1989; Smith and Lyon 2000) such as grouses and northern harriers(Kruse and Piehl 1984). Chicks and eggs are affected too (Palmisiano 2014), and nest parasitism may increase as a result of females ranging more widely in search of nest building materials (Best 1979).

Fires can also damage aquatic animals. Increases in water temperature and toxic chemicals, variations in $\mathrm{pH}$ (Gresswell 1999), turbidity (Gill and Allan 2008) and stream sedimentation (Bozek and Young 1994; Lyon and O'Connor 2008)have detrimental effects on fish, macroinvertebrates and emergent insects and amphibians in aquatic phases(Fish and Rucker 1945; Dunham et al. 2007). Excess sediment may crush or dislodge fish eggs, preventing the emergence of fry (Cooper 1965; Bjornn et al. 1977). This can induce physiological stress and growth reduction for fish (Newcombe and Macdonald 1991; 
Bozek and Young 1994). A cumulative impact from successive fires will affect the watershed's morphology in the long term (Moody and Martin 2001). Fish populations may be unable to recolonize fire-affected streams, as seen for salmonids one year after a fire (Rinne 1996). Post-fire sediments can be beneficial or detrimental to fish and aquatic macroinvertebrates by either providing resources or polluting habitat. Some fish species exhibit accelerated maturity rates by rapidly recolonizing post-fire channels along debris-flow runout paths (Goode et al. 2012). Further research is advisable on developing effective options to prevent potential damage that aquatic fauna may experience in post-fire conditions. Eventually, fires can impact marine animals as well. Post-fire heavy rains near the coast can causeashes to quickly reach the sea, wherein an increased mortality has been reported for shellfish, waders that feed on insects near the sea, river mussels and Kentish plover (EuropaPress 2016).

Although literature reports little or no direct postfire mortality for reptiles (Scott 1996; Russell et al. 1999; Smith and Lyon 2000), probably because mesic habitats tend to burn infrequently (Ford et al. 1999), some studies have found reductions in population density post-fire for five common species (Hossack 2006; Costa et al. 2013).

Arthropods can perish in the heat of the flames, and fire destroys their shelters and food. Eggs, nymphs, and adult stages may be affected, and fires can cause a long-term depression effect on populations (Lyon 1978). Decreases in soil fauna populations after a fire have been reported (Rickard 1970; Metz and Farrier 1973; Harris and Whitcomb 1974; Rinne 1996; Fellin and Kennedy 2014), including ticks not attached to a host animal, beetles, mites, aquatic macroinvertebrates, etc. Even after 2-6 years post-fire, invertebrate populations density may not reach pre-fire levels (Huhta et al. 1967; Vlug and Borden 1973). A significant decline in pollinators has been reported, concluding that future research on fire effects on plant-pollinator interactions are necessary (Brown et al. 2017).

There are currently no accurate estimates of the number of animals that die each year in fires. Quantifying exact post-fire mortality is practically impossible because bodies are often charred, some species are too small to be counted, and monitoring individuals for years until a fire occurs is tremendously complicated (Sutherland and Dickman 1999a).Moreover, mortality cannot be quantified by comparing population densities before and after a fire event, since a distinction would not be made between mortality and migration (Whelan 1995). In future, mortality quantification could make it possible to assess which areas have been most damaged and require wild animal welfare intervention, as well as raising public awareness. Post-fire immediate mortality is quantified by direct estimates, either through software (Jeffers et al. 1982; Silveira et al. 1999b), or relying on recent reports estimating animal populations sizes and excluding those species with the ability to flee (Dickman 2020).

\section{Acute heat stress response}

Animals' responses to fire depend on the particular characteristics of the fire itself, their habitat, their life history traits, how they manage their daily energy budget (Letnic 2001; Letnic et al. 2004; McGregor et al. 2014; Stawski et al. 2015a), and their individual 'stress coping styles' (Koolhaas et al. 1999)(the latter related to the individual's predisposition to frustration(Dawkins 1988)), and the animals' temperaments (Martin and Réale 2008) and personalities (Carere and Eens 2005).

Although the immediate physiological effects of fire exposure are poorly understood in animals, inferences can be drawn from studies of the effects of exposure to high environmental temperature(Engstrom 2010). Generally, cellular protein denaturation occurs from $50^{\circ} \mathrm{C}$ (Schmidt-Nielsen 1964), and temperatures higher than $63{ }^{\circ} \mathrm{C}$ are usually lethal (Howard et al. 1959; Smith and Lyon 2000). High environmental temperatures predispose animals to heat stress, which includes physiological and behavioural disturbances such as hyperventilation or loss of coordination (Radford et al. 2006). Heat stress effects are aggravated when accompanied by burns on limbs, feet and paws caused by the hot surfaces (Klein 1960; Lyon 1978).

Different consequences of acute heat stress previously reported in animals have included decreased food intake (Marai et al. 2007; Xing et al. 2019), hormonal, metabolic, hypothalamic and circadian alterations (Marai et al. 2007), epinephrine and norepinephrine increases (Johnson and Vanjonack 1976), tissue stress (Islam et al. 2013), respiratory rate and skin temperature increases, gonadal deleterious effects with litter size diminution (Askar and Ismail 2012), and stress-related behaviours (Debut et al. 2005).

Since wildfires frequently occur at the end of spring or during the summer, stress also hinders population recovery, reproduction and breeding 
(Koprowski 2005). Reduced forest cover may lead to higher temperatures that can affect cavity-nesting species, hindering incubation and nest survival (Neal et al. 1993; Wachob 1996; Conway 2000). Dead trees generate extreme temperatures inside nest cavities (Wiebe 2001), and both eggs and young birds are susceptible to heat stress. The survival of cavity-nesting birds is threatened in fires followed by rain since the activity of flying arthropods on which they feed decreases (Murphy and Lehnhausen 1998; Covert-Bratlandet al. 2006; Hutto 2006; Koivula and Schmiegelow 2007; Saab et al. 2007). Difficulty in acquiring food can increase the risk of nest abandonment (Neal et al. 1993; Conway 2000; Wiebe 2001; Jehle et al. 2004) and offspring mortality.

Heat stress impact can be reduced. For example, supplementation with olive oil in chickens alleviates superoxide anion production in the skeletal muscle (Mujahid et al. 2009). During prolonged dry periods and fires, drinking fountains can be placed in trees. Arboreal animals that are on the ground, and animals that show loss of balance, convulsions or confusion can be rescued with a towel, a well-ventilated box, or by offering them water (AWARE 2019).

\section{Flight from the fire}

The immediate post-fire environment generates a sudden drastic alteration of habitat structure and local microclimate that affects all terrestrial fauna (Lyon 1978). The consequent habitat simplification, including loss of vegetation cover and soil layer, may result in a reduction of the number of species after fire, as reported for rodents (Sutherland and Dickman 1999a). Likewise, aspects such as increased levels of sunlight penetrating the forest canopy and loss of food resources can affect behavioural search patterns (Barlow et al. 2002). As a result, many animals frequently move to fire-free areas (Brynard 1972; Recher and Christensen 1981), unburnt islands or surrounding unburnt vegetation (Begg 1981; Quinn 1979).

Moving to other places allows animals to access new resources, maintain homeostasis, find mates, and respond to predators, parasites and competitors. These functions eventually allow growth, survival and reproduction, which define fitness (Nathan et al. 2008; Weinstein et al. 2018). Movement is critical for species living in environments characterised by periodic change (Hanski 1999; Roshier et al. 2008), and regular fires (Nimmo et al. 2019). Low mobility animals will be more affected by smoke, high tem- peratures and oxygen shortage. For instance, while amphibians usually have limited migration abilities (Sinsch 1990), larger reptiles normally disperse skillfully from fire (Komarek 1969; Patterson 1984). Movement in vertebrates ranges from attraction (Komarek 1969) to avoidance (Nimmo et al. 2019) responses, ranging from calm escape to a state of panic and anxious movements (Komarek 1969; Lyon 1978). Tendency to flee depends on animal adaptations to high temperatures, like mud baths and burrowing (Quinn 1979). Moreover, some species have fire detection mechanisms even functional during torpor (Grafe et al. 2002; Scesny and Robbins 2006; Schmitz et al. 2008; Stawski et al. 2015a; Doty et al. 2018; Mendyk et al. 2019).

The study of post-fire movement patterns is crucial to understanding refuge seeking behaviour. Moving towards open areas can be especially favourable in fires accompanied by wind, since wind increases heat loss particularly if the animal is wet (Hart et al. 1961). However, other species (Rosenzweig et al. 1975; Price 1978; Price and Waser 1984) prefer foraging near cover and avoid approaching open areas (Glass 1969; Miller et al. 1972). Among the animals that decide to escape the flames (Geluso and Bragg 1986; Grafe et al. 2002), some small mammals species (Vacanti and Geluso 1985) have been found running from the fire, most commonly in groups in small clearings, depressions, road cuts and hiking trails (Quinn 1979), indicating specific flight patterns with preference for clear paths. Other mammals have been seen swimming along rivers to avoid the flames (Kozlowski 1974). While some of them may return within hours or days, others migrate because the food (King et al. 1997) and cover (Lyon and Marzluff 1985) they require are no longer available in the burnt area (Bradstock et al. 2005; Parr and Andersen 2006; Nimmo et al. 2013; Nimmo et al. 2019). Some radio-tracked individuals were transient and travelled $10 \mathrm{~km}$ or more to find patches with available resources in both burned and unburned areas (Letnic 2001). Large mammals tend to move calmly and act indifferently towards the fires near the fire borders (Phillips 1965; Sunquist 1967; Komarek 1969; Vogl 1973; Lyon 1978; Smith and Lyon 2000; Barkley 2019).

Moving to unburned areas is not the only way to survive a fire. Some species have beneficial adaptations such as torpor (Stawski et al. 2015b; Nowack et al. 2016; Matthews et al. 2017; Doty et al. 2018) and burrowing (Grafe et al. 2002; Garvey et al. 2010; 
Pike and Mitchell 2013), even occupying burrows made by another animal (Bradstock and Auld 1995). Lizards (Kahn 1960; Lillywhite and North 1974), frogs (Vogl 1973), turtles (Fenner and Bull 2007) and insects in mobile stages (Lyon 1978) have been seen burrowed during fires.

Hiding in burrows is not always a successful strategy. As the soil heats up, the air in the burrow becomes hotter and more humid (Kozlowski 1974). Burrow characteristics may expose animals to life-threatening challenges. Good ventilation (Bendell 1974; Hedlund and Rickard 1981), closeness to the surface, or multiple entries (Geluso and Bragg 1986) potentially reduce mortality risk of some species such as Lepidoptera and other univoltine pollinators (Carbone et al. 2019). The construction material is also relevant. Small rodents that build close-surface nests made of flammable materials have a higher vulnerability than species that nest deeper (Kaufman et al. 1988; Simons 1991; Quinn 1979). Survival chances in burrows will also depend on behaviour. Some rodents (Neotoma sp.) have been seen to refuse to leave the burrow during active burning fires (Simons 1991), whereas others (Sigmodon sp.) have been seen carrying young individuals with eyes still closed out of the burrows while fire approached (Komarek 1969).

The decision to move to another area is often accompanied by an inspection of the environment to identify settle options. If the fire has severely damaged the habitat, animals must face the difficulty of becoming oriented. They face increased risk of being preyed on (Johnson et al. 2009), and approaching urban areas, vehicles, and harmful chemicals. In fact, research on road ecology has recently been proposed to mitigate negative roadside behaviours (Proppe et al. 2017) . Due to altered vegetation or resource provisioning, roads can serve as attractants to animals. For this reason, a recent review concluded that road use contributes to the risk of collisions with vehicles (Hill et al. 2020). Furthermore, animal migration may also lead to the dispersal of infectious agents, which can have unpredictable effects and cause difficult-to-control diseases (Kirkwood and Sainsbury 1996). New infections can also occur in rescue veterinary hospitals (Kirkwood and Sainsbury 1996).

As a consequence of trophic relationships and resource distribution changes after migration, intraspecific and interspecific competition conflicts may determine post-fire colonisation success (Sutherland and Dickman 1999a) as reported for different species of rodents (Catling 1986; Higgs and Fox 1993), and animal community reorganization (Smith and Lyon 2000). Dominance in competition can be influenced by individual body size (Thompson and Fox 1993; Higgs and Fox 1993) and sex (Monamy and Fox 1999).

In view of the challenge of escaping from fire, some key aspects of management can be highlighted. First, unburnt patches and fire borders -frequented for example by ungulates in search of forage, bedding, cover, and thermal protection (Smith and Lyon 2000)- could be proposed as primary key areas for monitoring, rescue and supplementation. Second, further studies modelling the fluid dynamic processes of gases in burrows could facilitate understanding the challenges faced by burrowing animals (Engstrom 2010). Third, proper human behaviour towards animals is a crucial factor to prevent harm to animals that approach urban spaces, as found for five songbird species (Clucas and Marzluff 2012). Therefore, it is important to inform society on what actions can help or may further harm wild animals during fires. Finally, any accidental introduction of diseases in veterinary hospitals and rescue centres after a fire must be prevented by strict medical management protocols.

\section{Habitat modification}

Surviving a fire does not guarantee survival in the post-fire environment, which is characterised by habitat alteration, reduction in shelter and resource availability, competition changes, and increased predation risk (Sutherland and Dickman 1999b; Nimmo et al. 2014; Valentine et al. 2014; van Mantgem et al. 2015).

Fire generates extreme edaphic conditions and the drying of the soil alters bacterial and fungal activity, altering key biological processes. Since burned areas constitute their own local climate, specific behavioural responses within faunal populations occur (Lyon 1978). Specifically, fires cause light, temperature, soil heating and wind increases; humidity decrease; loss of nitrogen and carbon to the atmosphere; charcoal and ash depositions and physicochemical alterations in soil (Callaham et al. 2003; Certini 2005). Other specific alterations include increases in canopy fracture, higher rates of tree fall, a downward shift in the vertical stratification of foliage density, a marked increase in the amount of light reaching the understo- 
rey and forest floor (Peres et al. 2003), and increased solar heat input as a result of the low albedo of black charred soil and vegetation (Klein 1960).

Post-fire environmental alterations can often affect animal distribution and behaviour, eventually affecting welfare. For example, light and temperature excesses together with lack of humidity alter the distribution of different species of birds and small mammals (Ahlgren 1960; Gashwiler 1970; Beck and Vogl 1972), even causing mortality increases (Curry-Lindahl and Marcstrom 1961; Ritcey and Edwards 1963). Both shelter and movement are also reduced in mice and birds due to ash, burned soil, and removal of stem and fallen leaves (Cook 1959; Gashwiler 1970; Sims and Buckner 1973).

Species' environmental requirements determine their post-fire survival. For instance, populations requiring elevated perching sites on shrubs and logs and low vegetation for cover may noticeably decline(Friend 1993). Specialists and frugivores in need of canopy and other highly specific microhabitat may be restricted to narrow areas (such as moist, shaded understorey). Local extinctions and marked declines are frequent, as reported for antbirds (Barlow et al. 2002), army-ant swarms, pitheciine primates, and large psittacids (Peres et al. 2003). Furthermore, habitat changes are more damaging to highly sensitive species. For instance, amphibians, in addition to having restricted home ranges, have permeable skin vulnerable to flames. Unburned riparian areas likely buffer the stream immediately after the fire (Bury et al. 2002), being main zones to be protected following the fire.

Additionally, food seems to be an important postfire resource selection driver. In fact, time since fire significantly influences food resources (Valentine et al. 2014), and species can modify their diet to survive after a fire, especially in the early stages (Sutherland and Dickman 1999b). For instance, in a study on small mammals' diet, fungus, which is normally an insignificant component of their diet, became dominant after fire (Johnson 1996). Once fire eliminates resources such as nectar, fruits, seeds (Valentine et al. 2012; Valentine et al. 2014), lichens and cottongrass, forage behaviour in species is reduced (Jandt et al. 2008). In fact, some forages take years to recover (Bret-Harte et al. 2013; Zouaoui et al. 2014). As snags fall, foraging options decrease for many beetle-foraging species as well (Morissette et al. 2002). At the same time, fire is beneficial in some contexts for foraging and nesting behaviors of some spe- cies. For example, fire provides beneficial resources such as snags for bark forager and cavity-nesting birds (Hutto 1995; Lindenmayer et al. 2004; Saab et al. 2011). Although higher post-fire foraging and food-seeking behaviours are reported for some species (Begg 1981), the difficulty in finding food generated body condition reduction in some such as bush rats (Rattus fuscipes) (Fordyce et al. 2016).

Sometimes the post-fire practices of humans cause habitat disturbances that affect animals. For instance, post-fire salvage logging negatively affects deadwood-dependent species like beetles (Villard 1994; Murphy and Lehnhausen 1998; Nappi et al. 2003), and forest birds (Haggard and Gaines 2001; Kotliar et al. 2002; Morissette et al. 2002).

In this section it is relevant to mention that literature also shows numerous examples of the benefits of fire in habitats. There are numerous scientific studies emphasizing that fires are a key agent for the persistence of many ecosystems, such as savannahs, prairies, pine forests or Mediterranean scrublands (Whelan 1995, Orgeas \& Andersen 2001, Panzer 2002, Kauffman 2004, Keeley et al. 2005). Fires have been reported to benefit sometimes the regeneration of plant development and succession, the increase of biomass, the irregularity of the habitat, the diversity of food cover, the production of seeds of grasses and legumes, and even the increase in nutritional content and digestibility of plants (Smith \& Lyon 2000).

In addition, there is an extended evidence on the assumption that meeting needs of plant communities will automatically meet the needs of animal species (Clarke 2008). Previous research has reported that landscapes exposed to greater diversity of fire regimes generate greater diversity in the long term (Parr and Andersen 2006), stimulating very relevant organisms such as hypogenic fungi (Claridge et al. 2009); and that organisms can survive fire disturbances through evolutionary adaptations (Clarke 2008).

\section{Predation risk}

Predation is another significant risk that wild animals face due to fires. After a fire, many animals are visually more exposed to their predators, thus having greater vulnerability to being preyed on (Rickbeil et al. 2017), as reported for amphibians (Daly 2019), lizards (Shepard 2007) and termites (Prada and Marinho-Filho 2004). For some birds, nests placed in the post fire environment are closer to the ground due to the loss of taller stems, making hatchlings and adult birds more vulnerable to predation (Best 1979). 
Fires make animals more vulnerable to predators in other ways as well. Energy lost during flight from the fire makes prey animals weaker, increasing predation risk (Johnson et al. 2009). This is exacerbated by the increase in predation activity reported after a fire (Sutherland and Dickman 1999b; McGregor et al. 2014). Affinity for burned areas has been reported for wolves (Canis lupus) (Robinson et al. 2012), red foxes (Vulpes vulpes), feral cats (Feliscatus) (McGregor et al. 2016; Geary et al. 2019) and raptors (F. Falconidae) (Barnard 1987; Hovick et al. 2017).

Post-fire predation increases native mammal mortality and limits population recovery (Hradsky 2020). Some native species may not be accustomed to cope with invasive predators, so they might ignore cues indicating their presence. For instance, native rodents were 21 times more likely to die in areas exposed to intense fire compared to unburned areas, mostly due to predation by feral cats (Leahy et al. 2015).

Predation activity after a fire usually increases at the edges of the burned area, and some prey species remained less active in the edges until cover restoration (Parkins et al. 2019). Edge zones could be potentially more dangerous for many animals and rescue efforts could begin on the borders of the burn area.

However, there is a lack of research on the influence of flammable ecosystems' dynamics on animal activity patterns (Penn et al. 2003; Parkins et al. 2019). Mechanisms through which fire could create predation pinch points have been recently reviewed, and key questions about how to increase the resilience of native animals to fire in predator-invaded landscapes have been addressed (Hradsky 2020).

Both predation and competition have a central role in ecosystems, thus conservation science cannot always avoid challenging decisions regarding animal welfare (Sekar and Shiller 2020). Scientific evidence on post-fire predator activity needs to be increased. Understanding how ecosystem context and fire factors affect predator-predator and predator-prey relationships could prevent predation from exceeding adequate levels to maintain the ecosystem balance.

\section{Overview of wild animal management challenges}

Interventions on behalf of animals during fires face two main challenges. First, the evaluation of the behavioural responses of wild animals to identify key intervention points still needs to be expanded. This evaluation should consider influencing factors such as fire characteristics, environmental context (Whelan et al. 2002; Andersen et al. 2005; Geary et al.2019), habitat characteristics (Sutherland and Dickman 1999b), and individual stress coping styles (Koolhaas et al. 1999). Second, management of fire-affected animals must guarantee an overall evaluation and clinical assistance. The global state of the individual should be constantly evaluated, including burns, injuries, pre-existing diseases, mental and breathing status, dehydration level, level of shock, and stress due to handling and human proximity, (Fowler 2010). For instance, elderly koalas with advanced tooth wear will be unable to gain sufficient nutrition for the metabolic rate increase that burns require. Since they normally lose weight and starve during the rehabilitation process, veterinary protocol usually determines their euthanasia to avoid poor welfare (Fowler 2010).

Similarly, veterinarians should identify if infections arise during rehabilitation. For example, captive stress can aggravate chlamydiosis in koalas, and contagious individuals must be isolated. Moreover, adult individuals that are next to their dead calves when rescued should be separated to prevent the adult from contracting infection(Fowler 2010).

In the case of koalas, they are especially susceptible to "koala stress syndrome", characterized by lassitude, depression, anorexia and abrupt metabolic function decline. Koalas suffering from this syndrome are frequently found wandering aimlessly, or prostrate and comatose, with no evidence of trauma or overt illness. Captivity, surgeries, anaesthesia, and medical handling can provoke this syndrome (Obendorf 1983). Disorientation and weakness can enhance the probability of road approaches and vehicle collision, and consequent injuries (such as blindness, broken jaws, spines, and legs) that delay their rehabilitation.

Proper management of emergencies such as fires requires not waiting for the fire to occur, but developing pre-disaster efforts and well-organized protocols. In fact, the emergency management lifecycle has been thoroughly described (Heath and Linnabary 2015). For instance, pre-disaster planning can focus on increasing the commitment of the groups involved and improving community preparedness. Moreover, associations specialized in fire evacuations have already been developed and some of them include protocols focused on animals (Marsella and Sciarretta 2018). Animals can benefit from multidisciplinary efforts such as those carried out in the Australian 
fires in 2020, in which animals obtained the food that they otherwise could only have obtained with great difficulty from the infertile post-fire soils with irregular production and poorly digestible vegetation (Morton et al. 2011). The importance of providing food to starving individuals and medical assistance to injured or sick animals has been recently underlined (Faria 2015). Metabolic requirement varies when sick or hurt; therefore, once under rehabilitation, specific nutritional supplementation can be provided (Saito et al. 1987).

Feeding and water areas, easily arranged along the natural transects can supply many different species (Mella et al. 2019). Unless the rescuer is a veterinarian it is not recommended to provide water to animals before they arrive at the rescue center. Excessive rehydration can lead to subsequent kidney damage problems, and animals should never be bathed. For example, in the case of koalas it is recommended that the environment remain dark, quiet, warm and with an optimal humidity of $10 \%$ (Fowler 2010) .

Once in the rescue centre, the new environment in captivity can be a harmful factor for wild animals (Kleiman 1989; Biggins et al. 1999). Animals deprived of stimuli and space for a long time can display atypical behaviours and natural crucial skills such as anti-predator behaviour and food finding abilities can be compromised, especially for newborn individuals (Shier 2016). Anti-predator training, environmental enrichment, and soft release as pre-release conditioning tactics improved adaptive behaviour and post-release survival for fish, mammals, and reptiles (Tetzlaff et al. 2019).

In order for rescue centre environments to ensure similarity to natural habitat and interaction with co-specifics, environmental enrichment (Coleman and Novak 2017) must be considered. Simple initiatives like branch gum-feeders to simulate gum-foraging behaviour are inexpensive, low-maintenance methods that can be applied to various animals (Kreger 1999). New technologies such as Wi-Fi, LED projectors, and cameras can be used to give cognitive and visual enrichment, and monitor physiological variables (Coleman and Novak 2017). Exposure to natural scenes showing the species-typical environment caused beneficial psychological effects (Kahn et al. 2008; Mayer et al. 2009), such as decreased aggression (Kuo and Sullivan 2001), reduced autonomic activity (Parsons et al. 1998), and better surgical recovery along with reduced pain in a hospi- tal setting (Ulrich 1984).

Finally, reintroduction is the ultimate goal for rescued animals and it can prevent long-term population decline, especially in isolated areas likely to be destroyed in subsequent fires (Lunney et al. 2004a), as well as can restore individual animals' welfare (Mathews et al. 2006; Gelling et al. 2012; Harrington et al. 2013; Berg 2018). Reintroduction has been revised in recent years (Kolter and van Dijk 2005; Taggart et al. 2015; Harding et al. 2016; Taylor et al. 2017; Zamboni et al. 2017; Arumugam and Annavi 2019; Jourdan et al. 2019), including the assessment of potential health risks during translocation such as contagious diseases (Leighton 2002). The release should carefully follow re-introduction guidelines available for the species to minimize negative effects. Some aspects considered to assess reintroduction success are the individual's ability to avoid human activities, the minimization of a potential negative effect on the animal host population, and the survival and reproductive success of the individual herself (Kolter and van Dijk 2005). Generally, survival success of released animals is greater for individuals with better development (Muths et al. 2014), as well as in individuals released at their birthplace when compared to translocated ones (Fischer and Lindenmayer 2000).

Monitoring released individuals can be helpful to improve interventions (Muths et al. 2014), and examine fire effects (Engstrom 2010). Individual tagging can provide relevant information on how life history stage and season of fire influence fire-related mortality risk (Griffiths and Christian 1996). Further studies are needed regarding: (1) post-release success measurement in rehabilitated animals following fire and comparing information between individuals within the same population (Goldsworthy et al. 2000; Lunney et al. 2004a; Lunney et al. 2004b), and (2) sophistication and complexity of modern tracking methodologies (Griffiths and Pavajeau 2008). As an example, post-fire rehabilitated koalas were released and monitored for $>3$ months (NSW Government 2018). Koalas with limbs injuries received minimal intervention and high-quality nutrition, staying away from human contact to heal themselves. Results revealed that koalas healed better than if they had received regular treatments (Daniels 2018). Further investigation into animals' ability to recover from environmental disturbances and injuries may promote minimization of invasiveness. 


\section{Conclusions}

Considering that fires are expected to be more frequent and intense in the coming years, wild animals could be exposed to drastic modifications of their natural environment to which they are not adapted to flee and survive. Fires may increase the risk of injury, disease, stress, and mortality for animals living in the wild.

The consequences of fires can result in physiological and psychological damages, experiences of suffering, discomfort and pain, and long-term detrimental consequences.

There are substantial differences between different animal taxa. However, a wide variety of vertebrate species (and perhaps some invertebrates) are capable of experiencing physical and emotional pain, engaging in substantive relationships, and executing cognitively complex tasks (Clayton and Dickinson 1998; Braithwaite and Boulcott 2007; Bartal et al. 2011). This emphasizes that animal welfare is morally significant and policy-relevant (Sekar and Shiller 2020). The effects of fire on wild animals should be considered carefully. Individuals' responses depend on fire characteristics, habitat, life history traits, management of the daily energy budget of the species, and individual stress coping styles. Both active flight and remaining in burrows can severely compromise animal welfare.

Wild animals, especially more vulnerable ones can benefit from effective interventions in fires. All potential suffering, invasiveness, and discomfort during human proximity and handling should be avoided. Further efforts are necessary to expand scientific knowledge, develop multidisciplinary actions and increase social awareness.

\section{Future Perspectives}

The knowledge of the challenges and suffering to which wild animals are exposed in fires can facilitate interventions. In addition to the damage caused by the fire, research has shown that animals are vulnerable to the perceived stress of handling and captures (Obendorf 1983), which may add psychological and physiological damage. In fact, the faster the recovery and the greater the tolerance of an animal to a stressful event are, the lower the likelihood of such an event causing poor welfare (Morton 2007).

To overcome the current challenge that animal rescue actions in fires are focused on domestic animals (Linnabary 1993), awareness campaigns, roundtable events, and multidisciplinary approaches through technological advances are highly recommended.

The use of drones combined with automatic object recognition techniques to manual animal counting (van Gemert et al. 2015), centralized public telephone numbers and phone apps can facilitate interventions (White 2014). Media participation and information dissemination (Kolter and van Dijk 2005) may accelerate social interest and public awareness. In fire prone regions, community groups may be involved in interventions, raising awareness of their local environment (Lunney et al. 2004a).

Filling the current gaps in research can reveal new ways to help animals. As far as we know, the following list summarizes a sample of aspects that require further investigation.

- Behavioural responses (Smith and Lyon 2000; Penn et al. 2003; Banks et al. 2017) and physiological effects of fire for a large number of taxa.

- Modelling of gas fluid dynamics within burrows (Engstrom 2010).

- Replication of studies on the influence of morphological factors on the probability of success after a fire (Griffiths and Brook 2014).

- Monitoring the activity of pollinators after fires in different ecosystems (Carbone et al. 2019).

- Long-term stress after a fire in wild animals.

- Relationship between fire-related injuries and physical condition or premature post-fire mortality (Engstrom 2010).

- Population studies of tagged individuals before, during and after the fire to distinguish between mortality and migration (Driscoll et al. 2010; Conner et al. 2011).

- R\&D in effective options to prevent potential damage that aquatic fauna may experience in the harsh post-fire conditions .

- Relationship between post-fire food resource changes and diet modification (Begg 1981; Johnson 1996; Sutherland and Dickman 1999b) considering a review of nutrition requirements of fire-affected animals.

- Influence of post-fire activities such as logging on animal welfare (Koivula and Schmiegelow 2007), as evaluated for birds (Haggard and Gaines 2001; Kotliar et al. 2002; Morissette et al. 2002) and beetles (Villard 1994; Murphy and Lehnhausen 1998; Nappi et al. 2003). 
- Monitoring and management experiments understanding the mechanisms driving predator responses to fire, and potential broader effects (Hradsky et al. 2017; Geary et al. 2019). Multiple approaches measuring predator abundance, movement and diet are advisable.

- Self-healing ability to minimize invasiveness during interventions.

- New technologies developing environmental enrichment strategies for animals affected by fires (Tetzlaff et al. 2019). The consideration of animal temperaments to cover individualized needs during captivity (Coleman and Novak 2017) is recommended.

- Post-release success measurement in rehabilitated animals (Lunney et al. 2004b) and comparing information between individuals within the same population (Goldsworthy et al. 2000; Lunney et al. 2004a).

\section{ACKNOWLeGMents}

The authors appreciate all the effort and help received from Animal Ethics.

\section{FUNDING \\ Funded by Animal Ethics.}

\section{REFERENCES}

Ahlgren, C. E. (1960). Some Effects of Fire on Reproduction and Growth of Vegetation in Northeastern Minnesota. Ecology. doi:10.2307/1933318

Andersen, A. N., Cook, G. D., Corbett, L. K., Douglas, M. M., Eager, R. W., Russell-Smith, J., Setterfield, S. A., Williams, R. J., and Woinarski, J. C. Z. (2005). Fire frequency and biodiversity conservation in Australian tropical savannas: Implications from the Kapalga fire experiment. Austral Ecology. doi:10.1111/j.14429993.2005.01441.x

Anderson, N. B. (1998). Levels of analysis in health science: A framework for integrating sociobehavioral and biomedical research. In "Annals of the New York Academy of Sciences." doi:10.1111/j.1749-6632.1998. tb09595. $\mathrm{x}$

Arumugam, K. A., and Annavi, G. (2019). Captive Breeding of Threatened Mammals Native to Southeast Asia - A Review on their Ex-situ Management, Implication and Reintroduction Guidelines. Annual Research \& Review in Biology. doi:10.9734/arrb/2018/45921

Askar, A. A., and Ismail, E. I. (2012). Impact of heat stress exposure on some reproductive and physiological traits of rabbit does. Egyptian Journal of Animal Production 49, 151-159.
AWARE (2019). AWARE (Australian Wildlife Assistance Rescue and Education) Heat stress warning signs. Available at: https://www.awarewildlife.org.au/heatstressandwildlife/ [accessed 30 March 2020]

Banks, S. C., Cary, G. J., Smith, A. L., Davies, I. D., Driscoll, D. A., Gill, A. M., Lindenmayer, D. B., and Peakall, R. (2013). How does ecological disturbance influence genetic diversity? Trends in Ecology and Evolution. doi:10.1016/j.tree.2013.08.005

Banks, S. C., Dujardin, M., McBurney, L., Blair, D., Barker, M., and Lindenmayer, D. B. (2011a). Starting points for small mammal population recovery after wildfire: Recolonisation or residual populations? Oikos. doi:10.1111/j.1600-0706.2010.18765.x

Banks, S. C., Knight, E. J., McBurney, L., Blair, D., and Lindenmayer, D. B. (2011b). The effects of wildfire on mortality and resources for an arboreal marsupial: Resilience to fire events but susceptibility to fire regime change. PLOS ONE 6. doi:10.1371/journal. pone.0022952

Banks, S. C., McBurney, L., Blair, D., Davies, I. D., and Lindenmayer, D. B. (2017). Where do animals come from during post-fire population recovery? Implications for ecological and genetic patterns in post-fire landscapes. Ecography. doi:10.1111/ecog.02251

Barkley, Y. (2019). Wildfire and wildlife habitat. Available at: https://surviving-wildfire.extension.org/ wildfire-and-wildlife-habitat/ [accessed 3 November 2019]

Barlow, J., Haugaasen, T., and Peres, C. A. (2002). Effects of ground fires on understorey bird assemblages in Amazonian forests. Biological Conservation. doi:10.1016/S0006-3207(01)00177-X

Barlow, J., and Peres, C. A. (2004). Ecological responses to El Niño-induced surface fires in central Brazilian Amazonia: Management implications for flammable tropical forests. In "Philosophical Transactions of the Royal Society B: Biological Sciences." doi:10.1098/ rstb.2003.1423

Barnard, P. (1987). Foraging site selection by three raptors in relation to grassland burning in a montane habitat. African Journal of Ecology. doi:10.1111/j.1365-2028.1987.tb01088.x

Bartal, I. B. A., Decety, J., and Mason, P. (2011). Empathy and pro-social behavior in rats. Science. doi:10.1126/ science. 1210789

Beausoleil, N. J., and Mellor, D. J. (2015). Introducing breathlessness as a significant animal welfare issue. New Zealand Veterinary Journal. doi:10.1080/00480 169.2014.940410 
Beck, A. M., and Vogl, R. J. (1972). The Effects of Spring Burning on Rodent Populations in a Brush Prairie Savanna. Journal of Mammalogy. doi:10.2307/1379170

Begg, R. J. (1981). The small mammals of little nourlangie rock, n.t iii. ecology of dasyurus hallucatus, the northern quoll (marsupialia: Dasyuridae). Wildlife Research. doi:10.1071/WR9810073

Bendell, J. F. (1974). Effects of Fire on Birds and Mammals. In "Fire and Ecosystems." doi:10.1016/b978-012-424255-5.50009-2

Berg, C. (2018). Restoring what we have destroyed: animal welfare aspects of wildlife conservation, reintroduction and rewilding programmes. In "Animal welfare in a changing world." doi:10.1079/9781786392459.0068

Best, L. B. (1979). Effects of Fire on a Field Sparrow Population. American Midland Naturalist 101, 434. doi:10.2307/2424609

Biggins, D. E., Vargas, A., Godbey, J. L., and Anderson, S. H. (1999). Influence of prerelease experience on reintroduced black-footed ferrets (Mustela nigripes). Biological Conservation. doi:10.1016/S00063207(98)00158-X

Bjornn, T. C., Brusven, M. A., Molnau, M. P., Milligan, J. H., Klamt, R. A., Chacho, E., and Schaye, C. (1977). Transport of granitic sediment in streams and its effects on insects and fish. U. of I. Forest, Wildlife and Range Experiment Station, Bull. No. 17.

Bouaket, S. (1999). Forest Fires in Lao PDR. International Forest Fire News.

Bozek, M. A., and Young, M. K. (1994). Fish mortality resulting from delayed effects of fire in the Greater Yellowstone ecosystem. Great Basin Naturalist.

Bradstock, R. A., and Auld, T. D. (1995). Soil Temperatures During Experimental Bushfires in Relation to Fire Intensity: Consequences for Legume Germination and Fire Management in South-Eastern Australia. The Journal of Applied Ecology. doi:10.2307/2404417

Bradstock, R. A., Bedward, M., Gill, A. M., and Cohn, J. S. (2005). Which mosaic? A landscape ecological approach for evaluating interactions between fire regimes, habitat and animals. Wildlife Research. doi:10.1071/WR02114

Braithwaite, V. A., and Boulcott, P. (2007). Pain perception, aversion and fear in fish. Diseases of Aquatic Organisms. doi:10.3354/dao075131

Bret-Harte, M. S., Mack, M. C., Shaver, G. R., Huebner, D. C., Johnston, M., Mojica, C. A., Pizano, C., and Reiskind, J. A. (2013). The response of Arctic vegetation and soils following an unusually severe tundra fire. Philosophical Transactions of the Royal Society B: Biological Sciences. doi:10.1098/rstb.2012.0490
Brown, J., York, A., Christie, F., and McCarthy, M. (2017). Effects of fire on pollinators and pollination. Journal of Applied Ecology. doi:10.1111/1365-2664.12670

Brynard, A. M. (1972). Controlled burning in the Kruger National Park--history and development of a veld burning policy. Tall Timbers Fire Ecol Conf Proc. Available at: http://agris.fao.org/agris-search/search. do?recordID=US201302337593

Bury, R. B., Major, D. J., and Pilliod, D. (2002). Responses of Amphibians to Fire Disturbance in Pacific Northwest Forests : a Review. Proceedings: the role of fire for nongame wildlife management and community restoration: traditional uses and new directions. Gen. Tech. Rep. NE-288. Newtown Square, PA: US Dept. of Agriculture, Forest Service, Northeastern Research Station 288, 34-42.

Callaham, M. A., Blair, J. M., Todd, T. C., Kitchen, D. J., and Whiles, M. R. (2003). Macroinvertebrates in North American tallgrass prairie soils: Effects of fire, mowing, and fertilization on density and biomass. Soil Biology and Biochemistry. doi:10.1016/S00380717(03)00153-6

Campbell, M. (2016). What will the Fort McMurray fires mean for wildlife? Available at: https://www.macleans.ca/news/canada/where-the-wild-things-are-2/ [accessed 3 November 2019]

Carbone, L. M., Tavella, J., Pausas, J. G., and Aguilar, R. (2019). A global synthesis of fire effects on pollinators. Global Ecology and Biogeography. doi:10.1111/ geb.12939

Cardillo, M. (2003). Biological determinants of extinction risk: Why are smaller species less vulnerable? Animal Conservation. doi:10.1017/S1367943003003093

Carere, C., and Eens, M. (2005). Unravelling animal personalities: How and why individuals consistently differ. Behaviour. doi:10.1163/156853905774539436

Catling, P. C. (1986). Rattus lutreolus, colonizer of heathland after fire in the absence of pseudomys species? Wildlife Research. doi:10.1071/WR9860127

Certini, G. (2005). Effects of fire on properties of forest soils: A review. Oecologia. doi:10.1007/s00442-0041788-8

Claridge, A. W., Trappe, J. M., and Hansen, K. (2009). Do fungi have a role as soil stabilizers and remediators after forest fire? Forest Ecology and Management. doi:10.1016/j.foreco.2008.11.011

Clarke, M. F. (2008). Catering for the needs of fauna in fire management: Science or just wishful thinking? Wildlife Research. doi:10.1071/WR07137

Clayton, N. S., and Dickinson, A. (1998). Episodic-like memory during cache recovery by scrub jays. Nature. doi:10.1038/26216 
Clucas, A. B., and Marzluff, J. M. (2012). Attitudes and actions toward birds in urban areas: Human cultural differences influence bird behavior. The Auk 129, 8-16. doi:10.1525/auk.2011.11121

Cochrane, M. A., and Barber, C. P. (2009). Climate change, human land use and future fires in the Amazon. Global Change Biology. doi:10.1111/j.13652486.2008.01786.x

Coleman, K., and Novak, M. A. (2017). Environmental enrichment in the 21 st century. ILAR Journal. doi:10.1093/ilar/ilx008

Conner, L. M., Castleberry, S. B., and Derrick, A. M. (2011). Effects of mesopredators and prescribed fire on hispid cotton rat survival and cause-specific mortality. Journal of Wildlife Management. doi:10.1002/ jwmg. 110

Conway, C. J. (2000). Effects of ambient temperature on avian incubation behavior. Behavioral Ecology. doi:10.1093/beheco/11.2.178

Cook, S. F. (1959). The Effects of Fire on a Population of Small Rodents. Ecology. doi:10.2307/1929926

Cooper, A. C. (1965). The effect of transported stream sediments on the survival of sockeye and pink salmon eggs and alevins. Int. Pac. Salmon Fishery Commission Bulletin Bulletin.

Costa, B. M., Pantoja, D. L., Vianna, M. C. M., and Colli, G. R. (2013). Direct and Short-Term Effects of Fire on Lizard Assemblages from a Neotropical Savanna Hotspot. Journal of Herpetology. doi:10.1670/12-043

Cousins, R. A., Battley, P. F., Gartrell, B. D., and Powlesland, R. G. (2012). Impact injuries and probability of survival in a large semiurban endemic pigeon in new zealand, hemiphaga novaeseelandiae. Journal of Wildlife Diseases. doi:10.7589/0090-3558-48.3.567

COVERT-BRATLAND, K. A., BLOCK, W. M., and THEIMER, T. C. (2006). Hairy Woodpecker Winter Ecology in Ponderosa Pine Forests Representing Different Ages Since Wildfire. Journal of Wildlife Management. doi:10.2193/0022-541x(2006)70[1379:hwweip]2.0.co;2

Curry-Lindahl, K., and Marcstrom, V. (1961). Studies on the Physiological and Ecological Background to the Reproduction of the Capercaillie (Tetrao urogallus Lin.). The Journal of Wildlife Management. doi: $10.2307 / 3798686$

D'Antonio, C. M., and Vitousek, P. M. (1992). Biological invasions by exotic grasses, the grass/fire cycle, and global change. Annual Review of Ecology and Systematics. doi:10.1146/annurev.es.23.110192.000431

Daltry, J. C., and Momberg, F. (2000). "Cardamom Mountains: Biodiversity Survey 2000."
Daly, N. (2019). What the Amazon fires mean for wild animals. National Geographic. Available at: https:// www.nationalgeographic.com/animals/2019/08/ how-the-amazon-rainforest-wildfires-will-affectwild-animals/ [accessed 18 May 2020]

Daniels, P. (2018). Tagged koalas released back into the wild following Limeburners Creek fire. Available at: https://www.portnews.com.au/story/5371192/ port-macquarie-koala-hospital-releases-radio-collared-koalas/ [accessed 25 March 2020]

Davies, I. D., Cary, G. J., Landguth, E. L., Lindenmayer, D. B., and Banks, S. C. (2016). Implications of recurrent disturbance for genetic diversity. Ecology and Evolution. doi:10.1002/ece3.1948

Dawkins, M. S. (1988). Behavioural deprivation: A central problem in animal welfare. Applied Animal Behaviour Science. doi:10.1016/0168-1591(88)90047-0

Day, A. M. (2017). Companion animals and natural disasters: A systematic review of literature. International Journal of Disaster Risk Reduction 24, 81-90. doi:10.1016/j.ijdrr.2017.05.015

Debut, M., Berri, C., Arnould, C., Guemené, D., Santé-Lhoutellier, V., Sellier, N., Baéza, E., Jehl, N., Jégo, Y., Beaumont, C., and Le Bihan-Duval, E. (2005). Behavioural and physiological responses of three chicken breeds to pre-slaughter shackling and acute heat stress. British Poultry Science. doi:10.1080/00071660500303032

DeGrazia, D., and Rowan, A. (1991). Pain, suffering, and anxiety in animals and humans. Theoretical Medicine. doi:10.1007/BF00489606

Dickman, C. R. (2020). A statement about the 480 million animals killed in NSW bushfires since September. Available at: https://www.sydney.edu.au/news-opinion/news/2020/01/03/a-statement-about-the-480-million-animals-killed-in-nsw-bushfire.html [accessed 30 March 2020]

Doerr, S. H., and Santín, C. (2016). Global trends in wildfire and its impacts: Perceptions versus realities in a changing world. Philosophical Transactions of the Royal Society B: Biological Sciences. doi:10.1098/ rstb. 2015.0345

Doty, A. C., Currie, S. E., Stawski, C., and Geiser, F. (2018). Can bats sense smoke during deep torpor? Physiology and Behavior. doi:10.1016/j.physbeh.2017.12.019

Driscoll, D. A., Lindenmayer, D. B., Bennett, A. F., Bode, M., Bradstock, R. A., Cary, G. J., Clarke, M. F., Dexter, N., Fensham, R., Friend, G., Gill, M., James, S., Kay, G., Keith, D. A., MacGregor, C., Russell-Smith, J., Salt, D., Watson James, J. E. M., Williams Richard J., R. J., and York, A. (2010). Fire management 
for biodiversity conservation: Key research questions and our capacity to answer them. Biological Conservation. doi:10.1016/j.biocon.2010.05.026

Duncan, I. J., and Petherick, J. C. (1991). The implications of cognitive processes for animal welfare. Journal of animal science. doi:10.2527/1991.69125017x

Dunham, J. B., Rosenberger, A. E., Luce, C. H., and Rieman, B. E. (2007). Influences of wildfire and channel reorganization on spatial and temporal variation in stream temperature and the distribution of fish and amphibians. Ecosystems. doi:10.1007/s10021-0079029-8

Edmonds, A. S., and Cutter, S. L. (2008). Planning for Pet Evacuations during Disasters. Journal of Homeland Security and Emergency Management. doi:10.2202/1547-7355.1445

Engstrom, R. T. (2010). First-order fire effects on animals: Review and recommendations. Fire Ecology. doi:10.4996/fireecology.0601115

Ernst, C. H., Boucher, T. P., Sekscienski, S. W., and Wilgenbusch, J. C. (1999). Fire ecology and the Florida box turtle, Terrapene carolina bauri. NCASI Technical Bulletin.

Erwin, W. J., and Stasiak, R. H. (1979). Vertebrate Mortality During the Burning of a Reestablished Prairie in Nebraska. American Midland Naturalist. doi: $10.2307 / 2424922$

EuropaPress (2016). The other victims of fires: animals and plants. Available at: https://www.europapress.es/ sociedad/medio-ambiente-00647/noticia-otras-victimas-incendios-animales-plantas-20160818173800. html [accessed 2 December 2019]

Faria, C. (2015). Making a Difference on Behalf of Animals Living in the Wild: Interview with Jeff McMahan. Relations. doi:10.7358/rela-2015-001-fari

Fayt, P., Machmer, M. M., and Steeger, C. (2005). Regulation of spruce bark beetles by woodpeckers - A literature review. Forest Ecology and Management. doi:10.1016/j.foreco.2004.10.054

Fellin, D. G., and Kennedy, P. C. (2014). “Abundance of arthropods inhabiting duff and soil after prescribed burning on forest clearcuts in northern Idaho /." doi:10.5962/bhl.title. 81748

Fenner, A. L., and Bull, C. M. (2007). Short-term impact of grassland fire on the endangered pygmy bluetongue lizard. Journal of Zoology. doi:10.1111/j.14697998.2007.00287.x

Fischer, J., and Lindenmayer, D. B. (2000). An assessment of the published results of animal relocations. Biological Conservation. doi:10.1016/S00063207(00)00048-3
Fish, F. F., and Rucker, R. R. (1945). Columnaris as a Disease of Cold-Water Fishes. Transactions of the American Fisheries Society. doi:10.1577/1548-8659(1943)73[32:caadoc]2.0.co;2

Fisher, J. T., and Wilkinson, L. (2005). The response of mammals to forest fire and timber harvest in the North American boreal forest. Mammal Review. doi:10.1111/j.1365-2907.2005.00053.x

Flannigan, M., Stocks, B., Turetsky, M., and Wotton, M. (2009). Impacts of climate change on fire activity and fire management in the circumboreal forest. Global Change Biology. doi:10.1111/j.13652486.2008.01660.x

Ford, W. M., Menzel, M. A., McGill, D. W., Laerm, J., and McCay, T. S. (1999). Effects of a community restoration fire on small mammals and herpetofauna in the southern Appalachians. Forest Ecology and Management 114, 233-243. doi:10.1016/S0378$1127(98) 00354-5$

Fordyce, A., Hradsky, B. A., Ritchie, E. G., and Di Stefano, J. (2016). Fire affects microhabitat selection, movement patterns, and body condition of an Australian rodent (Rattus fuscipes). Journal of Mammalogy 97, 102-111. doi:10.1093/jmammal/gyv159

Forsyth, D. M., Gormley, A. M., Woodford, L., and Fitzgerald, T. (2012). Effects of large-scale high-severity fire on occupancy and abundances of an invasive large mammal in south-eastern Australia. Wildife Research. doi:10.1071/WR12033

Fowler, A. (2010). Treating Burnt Wildlife. Wildlife Health \& Conservation Centre415 Werombi Rd, Camden, NSW, 2570

Fox, B. J., and Pople, A. R. (1984). Experimental confirmation of interspecific competition between native and introduced mice. Australian Journal of Ecology. doi:10.1111/j.1442-9993.1984.tb01370.x

Friend, G. R. (1993). Impact of fire on small vertebrates in mallee woodlands and heathlands of temperate Australia: A review. Biological Conservation 65, 99-114. doi:10.1016/0006-3207(93)90439-8

Garvey, N., Ben-Ami, D., Ramp, D., and Croft, D. B. (2010). Survival behaviour of swamp wallabies during prescribed burning and wildfire. Wildlife Research. doi:10.1071/WR08029

Gasaway, W. C., Dubois, S. D., Boertje, R. D., Reed, D. J., and Simpson, D. T. (1989). Response of radio-collared moose to a large burn in central Alaska. Canadian Journal of Zoology. doi:10.1139/z89-047

Gashwiler, J. S. (1970). Plant and Mannal Changes on a Clearcut In West-Central Oregon. Ecology. doi: $10.2307 / 1933628$ 
Geary, W. L., Doherty, T. S., Nimmo, D. G., Tulloch, A. I. T., and Ritchie, E. G. (2019). Predator responses to fire. Journal of Animal Ecology 25, 259. doi: $10.2307 / 2256344$

Gelling, M., Johnson, P. J., Moorhouse, T. P., and Macdonald, D. W. (2012). Measuring animal welfare within a reintroduction: An assessment of different indices of stress in water voles Arvicola amphibius. PLOS ONE. doi:10.1371/journal.pone.0041081

Geluso, K. N., and Bragg, T. B. (1986). Fire-Avoidance Behavior of Meadow Voles (Microtus pennsylvanicus). American Midland Naturalist. doi:10.2307/2425953

van Gemert, J. C., Verschoor, C. R., Mettes, P., Epema, K., Koh, L. P., and Wich, S. (2015). Nature conservation drones for automatic localization and counting of animals. In "Lecture Notes in Computer Science (including subseries Lecture Notes in Artificial Intelligence and Lecture Notes in Bioinformatics)." doi:10.1007/978-3-319-16178-5_17

Gill, A. M., and Allan, G. (2008). Large fires, fire effects and the fire-regime concept. International Journal of Wildland Fire. doi:10.1071/WF07145

Glass, B. P. (1969). The Migratory Barren-Ground Caribou of Canada. John P. Kelsall . The Quarterly Review of Biology. doi:10.1086/406333

Goldsworthy, S. D., Giese, M., Gales, R. P., Brothers, N., and Hamill, J. (2000). Effects of the Iron baron oil spill on little penguins (Eudyptula minor). II. Post-release survival of rehabilitated oiled birds. Wildlife Research. doi:10.1071/WR99076

Goode, J. R., Luce, C. H., and Buffington, J. M. (2012). Enhanced sediment delivery in a changing climate in semi-arid mountain basins: Implications for water resource management and aquatic habitat in the northern Rocky Mountains. Geomorphology. doi:10.1016/j.geomorph.2011.06.021

Grafe, T. U., Döbler, S., and Linsenmair, K. E. (2002). Frogs flee from the sound of fire. Proceedings of the Royal Society B: Biological Sciences. doi:10.1098/ rspb.2002.1974

Gresswell, R. E. (1999). Fire and Aquatic Ecosystems in Forested Biomes of North America. Transactions of the American Fisheries Society. doi:10.1577/1548-8659(1999)128<0193:faaeif $>2.0$. co;2

Griffin, D. R., and Speck, G. B. (2004). New evidence of animal consciousness. Animal Cognition. doi:10.1007/s10071-003-0203-X

Griffiths, A. D., and Brook, B. W. (2014). Effect of fire on small mammals: A systematic review. International Journal of Wildland Fire. doi:10.1071/WF14026
Griffiths, A. D., and Christian, K. A. (1996). The effects of fire on the frillneck lizard (Chlamydosaurus kingii) in northern Australia. Austral Ecology. doi:10.1111/j.1442-9993.1996.tb00625.x

Griffiths, A. D., Garnett, S. T., and Brook, B. W. (2015). Fire frequency matters more than fire size: Testing the pyrodiversity-biodiversity paradigm for at-risk small mammals in an Australian tropical savanna. Biological Conservation 186, 337-346. doi:10.1016/j.biocon.2015.03.021

Griffiths, R. A., and Pavajeau, L. (2008). Captive breeding, reintroduction, and the conservation of amphibians. Conservation Biology. doi:10.1111/j.15231739.2008.00967.x

Haggard, M., and Gaines, W. L. (2001). Effects of stand-replacement fire and salvage logging on a cavity-nesting bird community in eastern Cascades, Washington. Northwest Science.

Hanski, I. (1999). Habitat Connectivity, Habitat Continuity, and Metapopulations in Dynamic Landscapes. Oikos. doi:10.2307/3546736

Harding, G., Griffiths, R. A., and Pavajeau, L. (2016). Developments in amphibian captive breeding and reintroduction programs. Conservation Biology. doi:10.1111/cobi.12612

Harrington, L. A., Moehrenschlager, A., Gelling, M., Atkinson, R. P. D., Hughes, J., and Macdonald, D. W. (2013). Conflicting and Complementary Ethics of Animal Welfare Considerations in Reintroductions. Conservation Biology. doi:10.1111/cobi.12021

Harris, D. L., and Whitcomb, W. H. (1974). Effects of Fire on Populations of Certain Species of Ground Beetles (Coleoptera: Carabidae). The Florida Entomologist. doi: $10.2307 / 3493841$

Hart, J. S., Heroux, O., Cottle, W. H., and Mills, C. A. (1961). The influence of climate on metabolic and thermal responses of infant caribou. Canadian Journal of Zoology. doi:10.1139/z61-079

Heath, S. E., and Linnabary, R. D. (2015). Challenges of managing animals in disasters in the U.S. Animals 5, 173-192. doi:10.3390/ani5020173

Heath, S., Voeks, S., and Glickman, L. (2000). A Study of Pet Rescue in Two Disasters. International journal of mass emergencies and disasters.

Hedlund, J. D., and Rickard, W. H. (1981). Wildfire and the Short-Term Response of Small Mammals Inhabiting a Sagebrush-Bunchgrass Community. The Murrelet. doi: $10.2307 / 3534441$

HIGGS, P., and FOX, B. J. (1993). Interspecific competition: A mechanism for rodent succession after fire in wet heathland. Australian Journal of Ecology. doi:10.1111/j.1442-9993.1993.tb00443.x 
Hill, J. E., De Vault, T. L., and Belant, J. L. (2020). A review of ecological factors promoting road use by mammals. Mammal Review. doi:10.1111/mam.12222

Horton, S. P., and Mannan, R. W. (1988). Effects of prescribed fire on snags and cavity-nesting birds in southeastern Arizona pine forests. Wildlife Society Bulletin. doi: $10.2307 / 3782350$

Hossack, B. R. (2006). Amphibians and wildfire in the U.S. Northwest. International Journal of Wilderness APRIL.

Hovick, T. J., Mcgranahan, D. A., Elmore, R. D., Weir, J. R., and Fuhlendorf, S. D. (2017). Pyric-carnivory: Raptor use of prescribed fires. Ecology and Evolution. doi:10.1002/ece3.3401

Howard, W. E., Fenner, R. L., and Childs, H. E. (1959). Wildlife Survival in Brush Burns. Journal of Range Management. doi:10.2307/3894992

Hradsky, B. A. (2020). Conserving Australia's threatened native mammals in predator-invaded, fire-prone landscapes. Wildlife Research. doi:10.1071/WR19027

Hradsky, B. A., Mildwaters, C., Ritchie, E. G., Christie, F., and Di Stefano, J. (2017). Responses of invasive predators and native prey to a prescribed forest fire. Journal of Mammalogy. doi:10.1093/jmammal/ gyx010

Huhta, V., Karppinen, E., Nurminen, M., and Valpas, A. (1967). Effect of silvicultural pratices upon arthropod, annelid and nematode populations in coniferous forest soil. Annales Zoologici Fennici.

Hutto, R. L. (2006). Toward meaningful snag-management guidelines for postfire salvage logging in North American conifer forests. Conservation Biology. doi:10.1111/j.1523-1739.2006.00494.x

Hutto, R. L. (1995). Composition of Bird Communities Following Stand-Replacement Fires in Northern Rocky Mountain (U.S.A.) Conifer Forests. Conservation Biology. doi:10.1046/j.1523-1739.1995.9051033.x-i1

Irvine, L. (2007). Ready or not: Evacuating an animal shelter during a mock emergency. Anthrozoos. doi:10.2752/089279307X245482

Isaac, J. L., Valentine, L. E., and Goodman, B. A. (2008). Demographic responses of an arboreal marsupial, the common brushtail possum (Trichosurus vulpecula), to a prescribed fire. Population Ecology. doi:10.1007/ s10144-007-0057-1

Islam, A., Abraham, P., Hapner, C. D., Andrews-Shigaki, B., Deuster, P., and Chen, Y. (2013). Heat exposure induces tissue stress in heat-intolerant, but not heat-tolerant, mice. Stress. doi:10.3109/10253890.2012.6967 54

Jandt, R., Joly, K., Meyers, C. R., and Racine, C. (2008). Slow recovery of lichen on burned caribou winter range in Alaska tundra: Potential influences of climate warming and other disturbance factors. Arctic, Antarctic, and Alpine Research. doi:10.1657/15230430(06-122)[JANDT]2.0.CO;2

Jeffers, J. N. R., Burnham, K. P., Anderson, D. R., and Laake, J. L. (1982). Estimation of Density from Line Transect Sampling of Biological Populations. The Journal of Ecology. doi:10.2307/2259887

Jehle, G., Yackel Adams, A. A., Savidge, J. A., and Skagen, S. K. (2004). Nest Survival Estimation: A Review of Alternatives to the Mayfield Estimator. The Condor. doi:10.1093/condor/106.3.472

Johnson, C. A., Fryxell, J. M., Thompson, I. D., and Baker, J. A. (2009). Mortality risk increases with natal dispersal distance in American martens. Proceedings of the Royal Society B: Biological Sciences. doi:10.1098/ rspb. 2008.1958

Johnson, C. N. (1996). Interactions between mammals and ectomycorrhizal fungi. Trends in Ecology and Evolution. doi:10.1016/S0169-5347(96)10053-7

Johnson, H. D., and Vanjonack, W. J. (1976). Effects of Environmental and Other Stressors on Blood Hormone Patterns in Lactating Animals. Journal of Dairy Science 59, 1603-1617. doi:10.3168/jds.S00220302(76)84413-X

Jolly, W. M., Cochrane, M. A., Freeborn, P. H., Holden, Z. A., Brown, T. J., Williamson, G. J., and Bowman, D. M. J. S. (2015). Climate-induced variations in global wildfire danger from 1979 to 2013. Nature Communications. doi:10.1038/ncomms 8537

Jourdan, J., Plath, M., Tonkin, J. D., Ceylan, M., Dumeier, A. C., Gellert, G., Graf, W., Hawkins, C. P., Kiel, E., Lorenz, A. W., Matthaei, C. D., Verdonschot, P. F. M., Verdonschot, R. C. M., and Haase, P. (2019). Reintroduction of freshwater macroinvertebrates: challenges and opportunities. Biological Reviews. doi:10.111/ brv. 12458

Kahn, P. H., Friedman, B., Gill, B., Hagman, J., Severson, R. L., Freier, N. G., Feldman, E. N., Carrère, S., and Stolyar, A. (2008). A plasma display window?-The shifting baseline problem in a technologically mediated natural world. Journal of Environmental Psychology. doi:10.1016/j.jenvp.2007.10.008

Kahn, W. C. (1960). Observations on the Effect of a Burn on a Population of Sceloporus Occidentilis. Ecology. doi: $10.2307 / 1930227$

Karki, S. (2002). "Community Involvement in and Management of Forest Fires in Community Involvement in and Management of Forest Fires in South East Asia."

Kauffman, J. B. (2004). Death rides the forest: Perceptions of fire, land use, and ecological restoration of western 
forests. Conservation Biology. doi:10.1111/j.15231739.2004.545_1.x

Kaufman, G. A., Kaufman, D. W., and Finck, E. J. (1988). Influence of Fire and Topography on Habitat Selection by Peromyscus maniculatus and Reithrodontomys megalotis in Ungrazed Tallgrass Prairie. Journal of Mammalogy. doi:10.2307/1381384

Keeley, J. E., Fotheringham, C. J., and Baer-Keeley, M. (2005). Factors affecting plant diversity during postfire recovery and succession of mediterranean-climate shrublands in California, USA. Diversity and Distributions. doi:10.1111/j.1366-9516.2005.00200.x

Keeley, J. E., and Syphard, A. D. (2016). Climate change and future fire regimes: Examples from California. Geosciences (Switzerland). doi:10.3390/geosciences6030037

Keith, L. B., and Surrendi, D. C. (1971). Effects of Fire on a Snowshoe Hare Population. The Journal of Wildlife Management. doi:10.2307/3799867

King, G. M., Bevis, K. R., Hanson, E. E., and Vitello, J. R. (1997). Northern spotted owl management: Mixing landscape and site-based approaches. Journal of Forestry. doi:10.1093/jof/95.8.21

KING, J. R., and FARNER, D. S. (1961). Energy Metabolism, Thermoregulation and Body Temperature. In "Biology and Comparative Physiology of Birds." doi:10.1016/b978-1-4832-3143-3.50014-9

Kirkwood, J. K., and Sainsbury, A. W. (1996). Ethics of interventions for the welfare of free-living wild animals. Animal Welfare 5, 235-243.

Kleiman, D. G. (1989). Reintroduction of Captive Mammals for Conservation. BioScience. doi:10.2307/1311025

Klein, H. G. (1960). Ecological Relationships of Peromyscus leucopus noveboracensis and P. maniculatus gracilis in Central New York. Ecological Monographs. doi:10.2307/1948434

Koivula, M. J., and Schmiegelow, F. K. A. (2007). Boreal woodpecker assemblages in recently burned forested landscapes in Alberta, Canada: Effects of post-fire harvesting and burn severity. Forest Ecology and Management. doi:10.1016/j.foreco.2007.01.075

Kolter, L., and van Dijk, J. (2005). Rehabilitation and Release of Bears: For the Welfare of Conservation or the Conservation of Welfare.

Komarek, E. V. (1969). Fire and animal behavior. In "Tall Timbers Fire Ecology Conference 9."

Koolhaas, J. M., Korte, S. M., De Boer, S. F., Van Der Vegt, B. J., Van Reenen, C. G., Hopster, H., De Jong, I. C., Ruis, M. A. W., and Blokhuis, H. J. (1999). Coping styles in animals: Current status in behavior and stress- physiology. Neuroscience and Biobehavioral Reviews. doi:10.1016/S0149-7634(99)00026-3

Koprowski, J. L. (2005). Annual cycles in body mass and reproduction of endangered $\mathrm{mt}$. graham red squirrels. Journal of Mammalogy. doi:10.1644/bwg-232.1

Koprowski, J. L., Leonard, K. M., Zugmeyer, C. A., and Jolley, J. L. (2006). Direct Effects of Fire on Endangered Mount Graham Red Squirrels. The Southwestern Naturalist 51, 59-63. doi:10.1894/0038-4909(20 06)51[59:deofoe $] 2.0 . c 0 ; 2$

Korte, S. M., Bouws, G. A. H., and Bohus, B. (1993). Central actions of corticotropin-releasing hormone (CRH) on behavioral, neuroendocrine, and cardiovascular regulation: Brain corticoid receptor involvement. Hormones and Behavior. doi:10.1006/ hbeh.1993.1013

Kotliar, N. B., Hejl, S. J., Hutto, R. L., Saab, V. A., Melcher, C. P., and McFadzen, M. E. (2002). Effects of fire and post-fire salvage logging on avian communities in conifer-dominated forests of the western United States. In "Studies in Avian Biology."

Kozlowski, T. (1974). "Fire and ecosystems." (Elsevier.)

Kreger, M. (1999). Environmental Enrichment for Nonhuman Primates Resource Guide. ILAR Journal.

Krikken, F., Lehner, F., Haustein, K., Drobyshev, I., and van Oldenborgh, G. J. (2019). Attribution of the role of climate change in the forest fires in Sweden 2018. Natural Hazards and Earth System Sciences. doi:10.5194/nhess-2019-206

Kruse, A. D., and Piehl, J. L. (1984). The Impact of Prescribed Burning on Ground-nesting Birds. Proceedings of the Ninth North American Prairie Conference, 153-156.

Kuo, F. E., and Sullivan, W. C. (2001). Aggression and violence in the inner city, effects of environment via mental fatigue. Environment and Behavior. doi:10.1177/00139160121973124

Lawrence, G. E. (1966). Ecology of Vertebrate Animals in Relation to Chaparral Fire in the Sierra Nevada Foothills. Ecology. doi:10.2307/1933775

Leahy, L., Legge, S. M., Tuft, K., McGregor, H. W., Barmuta, L. A., Jones, M. E., and Johnson, C. N. (2015). Amplified predation after fire suppresses rodent populations in Australia's tropical savannas. Wildlife Research 42, 705-716. doi:10.1071/WR15011

Lee, D. Y., Kim, E., and Choi, M. H. (2015). Technical and clinical aspects of cortisol as a biochemical marker of chronic stress. BMB Reports. doi:10.5483/BMBRep.2015.48.4.275 
Leighton, F. A. (2002). Health risk assessment of the translocation of wild animals. OIE Revue Scientifique et Technique. doi:10.20506/rst.21.1.1324

Letnic, M. (2001). Long distance movements and the use of fire mosaics by small mammals in the Simpson Desert, Central Australia. Australian Mammalogy. doi:10.1071/AM01125

Letnic, M., Dickman, C. R., Tischler, M. K., Tamayo, B., and Beh, C. L. (2004). The responses of small mammals and lizards to post-fire succession and rainfall in arid Australia. Journal of Arid Environments. doi:10.1016/j.jaridenv.2004.01.014

Lillywhite, H. B., and North, F. (1974). Perching Behavior of Sceloporus occidentalis in Recently Burned Chaparral. Copeia. doi:10.2307/1443035

Lindenmayer, D. B., Foster, D. R., Franklin, J. F., Hunter, M. L., Noss, R. F., Schmiegelow, F. A., and Perry, D. (2004). Salvage Harvesting Policies after Natural Disturbance. Science. doi:10.1126/science.1093438

Linnabary, R. D. (1993). Emergency evacuation of horses: a madison county, Kentucky survey. Journal of Equine Veterinary Science. doi:10.1016/S07370806(07)80235-8

Lnìons, G. B., Tanton, M. T., and Davey, S. M. (1989). Effect of fire on the availability of hollows in trees used by the common brushtail possum, trichosurus vulpecula kerr, 1792, and the ringtail possum, pseudocheirus peregrinus boddaerts, 1785. Wildlife Research. doi:10.1071/WR9890449

Lunney, D., Gresser, S. M., Mahon, P. S., and Matthews, A. (2004a). Post-fire survival and reproduction of rehabilitated and unburnt koalas. Biological Conservation 120, 567-575. doi:10.1016/j.biocon.2004.03.029

Lunney, D., Gresser, S. M., Mahon, P. S., and Matthews, A. (2004b). Post-fire survival and reproduction of rehabilitated and unburnt koalas. Biological Conservation. doi:10.1016/j.biocon.2004.03.029

Lyon, J. P., and O'Connor, J. P. (2008). Smoke on the water: Can riverine fish populations recover following a catastrophic fire-related sediment slug? Austral Ecology. doi:10.1111/j.1442-9993.2008.01851.x

Lyon, L. J. (1978). National Fire Effects Workshop: Effects of fire on fauna. A state-of-knowledge review. Forest Service National Fire Effects Workshop, Denver, Colo. (USA). Available at: AZTNC

Lyon, L. J., and Marzluff, J. M. (1985). Fire's effects on a small bird population. Fire's effects on wildlife habitat. Proc. symposium, Missoula, 1984.

van Mantgem, E. F., Keeley, J. E., and Witter, M. (2015). Faunal responses to fire in chaparral and sage scrub in California, USA. Fire Ecology. doi:10.4996/fireecology. 1103128
Marai, I. F. M., El-Darawany, A. A., Fadiel, A., and Abdel-Hafez, M. A. M. (2007). Physiological traits as affected by heat stress in sheep-A review. Small Ruminant Research. doi:10.1016/j.smallrumres.2006.10.003

Marsella, S., and Sciarretta, N. (2018). CBRN Events and Mass Evacuation Planning. In (Ed In Enhancing CBRNE Safety \& Security: Proceedings of the SICC 2017 Conference.) pp. 353-363. (Springer, Cham.)

Martin, J. G. A., and Réale, D. (2008). Animal temperament and human disturbance: Implications for the response of wildlife to tourism. Behavioural Processes. doi:10.1016/j.beproc.2007.06.004

Mathews, F., Moro, D., Strachan, R., Gelling, M., and Buller, N. (2006). Health surveillance in wildlife reintroductions. Biological Conservation. doi:10.1016/j. biocon.2006.04.011

Matthews, J. K., Stawski, C., Körtner, G., Parker, C. A., and Geiser, F. (2017). Torpor and basking after a severe wildfire: mammalian survival strategies in a scorched landscape. Journal of Comparative Physiology B: Biochemical, Systemic, and Environmental Physiology. doi:10.1007/s00360-016-1039-4

Mayer, F. S., Frantz, C. M. P., Bruehlman-Senecal, E., and Dolliver, K. (2009). Why is nature beneficial?: The role of connectedness to nature. Environment and Behavior. doi:10.1177/0013916508319745

McEwen, B. S. (2005). Stressed or stressed out: What is the difference? In "Journal of Psychiatry and Neuroscience."

McGregor, H. W., Legge, S., Jones, M. E., and Johnson, C. N. (2016). Extraterritorial hunting expeditions to intense fire scars by feral cats. Scientific Reports. doi:10.1038/srep22559

McGregor, H. W., Legge, S., Jones, M. E., and Johnson, C. N. (2014). Landscape management of fire and grazing regimes alters the fine-scale habitat utilisation by feral cats. PLOS ONE. doi:10.1371/journal.pone.0109097

Mella, V. S. A., McArthur, C., Krockenberger, M. B., Frend, R., and Crowther, M. S. (2019). Needing a drink: Rainfall and temperature drive the use of free water by a threatened arboreal folivore. PLOS ONE. doi:10.1371/journal.pone.0216964

Mendyk, R. W., Weisse, A., and Fullerton, W. (2019). A wake-up call for sleepy lizards: the olfactory-driven response of Tiliqua rugosa (Reptilia: Squamata: Sauria) to smoke and its implications for fire avoidance behavior. Journal of Ethology. doi:10.1007/s10164019-00628-z

Metz, L. J., and Farrier, M. H. (1973). Prescribed Burning and Populations of Soil Mesofauna. Environmental Entomology. doi:10.1093/ee/2.3.433 
Michetti, M., and Pinar, M. (2019). Forest Fires Across Italian Regions and Implications for Climate Change: A Panel Data Analysis. Environmental and Resource Economics. doi:10.1007/s10640-018-0279-z

Miller, F. L., Broughton, E., and Land, E. M. (1972). Moose fatality resulting from overextension of range. Journal of wildlife diseases. doi:10.7589/0090-35588.1 .95

Monamy, V., and Fox, B. J. (1999). Habitat Selection by Female Rattus lutreolus Drives Asymmetric Competition and Coexistence with Pseudomys higginsi. Journal of Mammalogy. doi:10.2307/1383223

Moody, J. A., and Martin, D. A. (2001). Initial hydrologic and geomorphic response following a wildfire in the Colorado front range. Earth Surface Processes and Landforms. doi:10.1002/esp.253

Morissette, J. L., Cobb, T. P., Brigham, R. M., and James, P. C. (2002). The response of boreal forest songbird communities to fire and post-fire harvesting. Canadian Journal of Forest Research. doi:10.1139/x02-134

Morton, D. B. (2007). A hypothetical strategy for the objective evaluation of animal well-being and quality of life using a dog model. Animal Welfare.

Morton, S. R., Stafford Smith, D. M., Dickman, C. R., Dunkerley, D. L., Friedel, M. H., McAllister, R. R. J., Reid, J. R. W., Roshier, D. A., Smith, M. A., Walsh, F. J., Wardle, G. M., Watson, I. W., and Westoby, M. (2011). A fresh framework for the ecology of arid Australia. Journal of Arid Environments. doi:10.1016/j. jaridenv.2010.11.001

Mujahid, A., Akiba, Y., and Toyomizu, M. (2009). Olive oil-supplemented diet alleviates acute heat stress-induced mitochondrial ROS production in chicken skeletal muscle. American Journal of Physiology Regulatory Integrative and Comparative Physiology. doi:10.1152/ajpregu.90974.2008

Murphy, E. C., and Lehnhausen, W. A. (1998). Density and Foraging Ecology of Woodpeckers Following a Stand-Replacement Fire. The Journal of Wildlife Management. doi:10.2307/3802002

Muths, E., Bailey, L. L., and Watry, M. K. (2014). Animal reintroductions: An innovative assessment of survival. Biological Conservation. doi:10.1016/j.biocon.2014.02.034

Nappi, A., Drapeau, P., Giroux, J.-F., and Savard, J.P. L. (2003). Snag use by Foraging Black-Backed Woodpeckers (Picoides Arcticus) in a Recently Burned Eastern Boreal Forest. The Auk. doi:10.1093/ auk/120.2.505

Nathan, R., Getz, W. M., Revilla, E., Holyoak, M., Kadmon, R., Saltz, D., and Smouse, P. E. (2008). A movement ecology paradigm for unifying organismal movement research. Proceedings of the National Academy of Sciences of the United States of America. doi:10.1073/pnas.0800375105

Neal, J. C., James, D. A., Montague, W. G., and Johnson, J. E. (1993). Effects of weather and helpers on survival of nestling red-cockaded woodpeckers. Wilson Bulletin.

Newcombe, C. P., and Macdonald, D. D. (1991). Effects of Suspended Sediments on Aquatic Ecosystems. North American Journal of Fisheries Management. doi:10.1577/1548-8675(1991)011<0072:eossoa $>2.3$. co;2

Nimmo, D. G., Avitabile, S., Banks, S. C., Bliege Bird, R., Callister, K., Clarke, M. F., Dickman, C. R., Doherty, T. S., Driscoll, D. A., Greenville, A. C., Haslem, A., Kelly, L. T., Kenny, S. A., Lahoz-Monfort, J. J., Lee, C., Leonard, S., Moore, H., Newsome, T. M., Parr, C. L., Ritchie, E. G., Schneider, K., Turner, J. M., Watson, S., Westbrooke, M., Wouters, M., White, M., and Bennett, A. F. (2019). Animal movements in fireprone landscapes. Biological Reviews 94, 981-998. doi: $10.1111 /$ brv. 12486

Nimmo, D. G., Kelly, L. T., Farnsworth, L. M., Watson, S. J., and Bennett, A. F. (2014). Why do some species have geographically varying responses to fire history? Ecography. doi:10.1111/ecog.00684

Nimmo, D. G., Kelly, L. T., Spence-Bailey, L. M., Watson, S. J., Taylor, R. S., Clarke, M. F., and Bennett, A. F. (2013). Fire Mosaics and Reptile Conservation in a Fire-Prone Region. Conservation Biology. doi:10.1111/j.1523-1739.2012.01958.x

Nowack, J., Cooper, C. E., and Geiser, F. (2016). Cool echidnas survive the fire. Proceedings of the Royal Society B: Biological Sciences. doi:10.1098/ rspb.2016.0382

NSW Government (2018). NSW Koala Country. Available at: https://koala.nsw.gov.au/nsw-government/ [accessed 25 March 2020]

Obendorf, D. L. (1983). Causes of mortality and morbidity of wild koalas, Phascolarctos cinereus (Goldfuss), in Victoria, Australia. Journal of wildlife diseases. doi:10.7589/0090-3558-19.2.123

Oliver, C. D., Osawa, A., and Camp, A. (1997). Forest dynamics and resulting animal and plant population changes at the stand and landscape levels. Journal of Sustainable Forestry. doi:10.1300/J091v06n03_05

Orgeas, J., and Andersen, A. N. (2001). Fire and biodiversity: Responses of grass-layer beetles to experimental fire regimes in an Australian tropical savanna. Journal of Applied Ecology. doi:10.1046/ j.1365-2664.2001.00575.x 
Palmisiano, J. (2014). Logging in national parks and forests: A contentious debate. Available at: https://lawstreetmedia.com/issues/energy-and-environment/ should-logging-be-encouraged-in-national-parksand-forests-under-hr-1526/ [accessed 2 December 2019]

Panzer, R. (2002). Compatibility of prescribed burning with the conservation of insects in small, isolated prairie reserves. Conservation Biology. doi:10.1046/ j.1523-1739.2002.01077.x

Parkins, K., Scott, A., Di Stefano, J., Swan, M., Sitters, H., and York, A. (2019). Habitat use at fire edges: Does animal activity follow temporal patterns of habitat change? Forest Ecology and Management 451, 117343. doi:10.1016/j.foreco.2019.05.013

Parks, S. A., Miller, C., Abatzoglou, J. T., Holsinger, L. M., Parisien, M. A., and Dobrowski, S. Z. (2016). How will climate change affect wildland fire severity in the western US? Environmental Research Letters. doi:10.1088/1748-9326/11/3/035002

Parr, C. L., and Andersen, A. N. (2006). Patch mosaic burning for biodiversity conservation: A critique of the pyrodiversity paradigm. Conservation Biology. doi:10.1111/j.1523-1739.2006.00492.x

Parsons, R., Tassinary, L. G., Ulrich, R. S., Hebl, M. R., and Grossman-Alexander, M. (1998). The view from the road: Implication for the stress recovry and immunization. Journal of Environmental Psychology. doi:10.1006/jevp.1998.0086

Patterson, G. B. (1984). The effect of burning-off tussock grassland on the population density of common skinks. New Zealand Journal of Zoology. doi:10.1080 /03014223.1984.10423757

Penn, A. M., Sherwin, W. B., Lunney, D., and Banks, P. B. (2003). The effects of a low-intensity fire on small mammals and lizards in a logged, burnt forest. Wildlife Research 30, 477-486. doi:10.1071/WR02080

Peres, C. A. (1999). Ground fires as agents of mortality in a Central Amazonian forest. Journal of Tropical Ecology. doi:10.1017/S0266467499000991

Peres, C. A., Barlow, J., and Haugaasen, T. (2003). Vertebrate responses to surface wildfires in a central Amazonian forest. Oryx 37, 97-109. doi:10.1017/ S0030605303000188

Phillips, J. (1965). Fire - as Master and Servant: Its Influence in the Bio-climatic Regions of Trans-Saharan Africa. Proceedings of the 4th Annual Tall Timbers Fire Ecology Conference, 66-100. Available at: https://talltimbers.org/wp-content/uploads/2018/09/ Phillips1965_op.pdf
Pike, D. A., and Mitchell, J. C. (2013). Burrow-dwelling ecosystem engineers provide thermal refugia throughout the landscape. Animal Conservation. doi:10.1111/ acv. 12049

Prada, M., and Marinho-Filho, J. (2004). Effects of fire on the abundance of xenarthrans in Mato Grosso, Brazil. Austral Ecology. doi:10.1111/j.14429993.2004.01391.x

Prasad, V. D., Kumar, P. R., Sreenu, M., and Harikrishna, N. V. V (2016). Management of Burns in Companion Animals : A Report of Three Cases. 5, 21-24.

Price, M. V. (1978). The Role of Microhabitat in Structuring Desert Rodent Communities. Ecology. doi: $10.2307 / 1938543$

Price, M. V., and Waser, N. M. (1984). On the relative abundance of species: postfire changes in a coastal sage scrub rodent community. Ecology. doi:10.2307/1938324

Proppe, D. S., McMillan, N., Congdon, J. V., and Sturdy, C. B. (2017). Mitigating road impacts on animals through learning principles. Animal Cognition. doi:10.1007/s10071-016-0989-y

Quinn, R. D. (1979). Effect of fire in small mammals Chaparral. Cal-Neva Wildlife Transactions

Radford, S. L., McKee, J., Goldingay, R. L., and Kavanagh, R. P. (2006). The protocols for koala research using radio-collars: A review based on its application in a tall coastal forest in New South Wales and the implications for future research projects. Australian Mammalogy. doi:10.1071/AM06027

Randerson, J. T., Chen, Y., Van Der Werf, G. R., Rogers, B. M., and Morton, D. C. (2012). Global burned area and biomass burning emissions from small fires. Journal of Geophysical Research G: Biogeosciences. doi:10.1029/2012JG002128

Recher, H. F., and Christensen, P. E. (1981). Fire and the evolution of the Australian biota. doi:10.1007/97894-009-8629-9_7

Rethorst, D. N., Spare, R. K., and Kellenberger, J. L. (2018). Wildfire Response in Range Cattle. Veterinary Clinics of North America - Food Animal Practice 34, 281-288. doi:10.1016/j.cvfa.2018.02.004

Rickard, W. H. (1970). Ground Dwelling Beetles in Burned and Unburned Vegetation. Journal of Range Management. doi:10.2307/3896224

Rickbeil, G. J. M., Hermosilla, T., Coops, N. C., White, J. C., and Wulder, M. A. (2017). Barren-ground caribou (Rangifer tarandus groenlandicus) behaviour after recent fire events; integrating caribou telemetry data with Landsat fire detection techniques. Global Change Biology 23, 1036-1047. doi:10.1111/gcb.13456 
Rinne, J. N. (1996). Management Briefs: Short-Term Effects of Wildfire on Fishes and Aquatic Macroinvertebrates in the Southwestern United States. North American Journal of Fisheries Management. doi:10.1 577/1548-8675(1996)016<0653:mbsteo >2.3.co;2

Ritcey, R. W., and Edwards, R. Y. (1963). Grouse Abundance and June Temperatures in Wells Gray Park, British Columbia. The Journal of Wildlife Management. doi:10.2307/3798474

Robinson, H. S., Hebblewhite, M., DeCesare, N. J., Whittington, J., Neufeld, L., Bradley, M., and Musiani, M. (2012). The effect of fire on spatial separation between wolves and caribou. Rangifer, 277-294. doi:10.7557/2.32.2.2276

Rodrigues, M., Trigo, R. M., Vega-García, C., and Cardil, A. (2020). Identifying large fire weather typologies in the Iberian Peninsula. Agricultural and Forest Meteorology. doi:10.1016/j.agrformet.2019.107789

Rosenzweig, M. L., Smigel, B., and Kraft, A. (1975). Patterns of Food, Space and Diversity. doi:10.1007/97894-010-1944-6_12

Roshier, D. A., Doerr, V. A. J., and Doerr, E. D. (2008). Animal movement in dynamic landscapes: Interaction between behavioural strategies and resource distributions. Oecologia. doi:10.1007/s00442-008-0987-0

Russell, K. R., Lear, D. H. Van, and Guynn, D. C. (1999). Herpetofauna : and Management Implications. Wildlife Society Bulletin 27, 374-384.

Saab, V. A., Russell, R. E., and Dudley, J. G. (2007). Nest Densities of Cavity-Nesting Birds in Relation to Postfire Salvage Logging and Time Since Wildfire. The Condor. doi:10.1093/condor/109.1.97

Saab, V. A., Russell, R. E., Rotella, J., and Dudley, J. G. (2011). Modeling nest survival of cavity-nesting birds in relation to postfire salvage logging. Journal of Wildlife Management 75, 794-804. doi:10.1002/ jwmg. 111

Saito, H., Trocki, O., Alexander, J. W., Kopcha, R., Heyd, T., and Joffe, S. N. (1987). The effect of route of nutrient administration on the nutritional state, catabolic hormone secretion, and gut mucosal integrity after burn injury. Journal of Parenteral and Enteral Nutrition. doi:10.1177/014860718701100101

Scesny, A. A., and Robbins, L. W. (2006). Detection of fire by eastern red bats (Lasiurus borealis) Arousal from torpor. Bat Research News.

Schmidt-Nielsen, K. (1964). "Desert animals Physiological problems of heat and water."

Schmitz, H., Schmitz, A., Kreiss, E., Gebhardt, M., and Gronenberg, W. (2008). Navigation to forest fires by smoke and infrared reception: The specialized sensory systems of "fire-loving" beetles. In "Navigation, Journal of the Institute of Navigation." doi:10.1002/j.2161-4296.2008.tb00424.x

Scott, N. J. J. (1996). Evolution and Management of the North American Grassland Herpetofauna. In "Ecosystem Disturbance and Wildlife Conservation in Western Grasslands."

Sekar, N., and Shiller, D. (2020). Engage with animal welfare in conservation. Science. doi:10.1126/science. aba7271

Shepard, D. B. (2007). Habitat but not body shape affects predator attack frequency on lizard models in the brazilian cerrado. Herpetologica. doi:10.1655/0018-0831(2007)63[193:hbnbsa]2.0. co;2

Sherwin, C. M. (2001). Can invertebrates suffer? Or, how robust is argument-by-analogy? Animal Welfare.

Shier, D. M. (2016). "Manipulating animal behaviour to ensure reintroduction success" Conservati.

Silveira, L., Henrique, F., Rodrigues, G., de Almeida Jácomo, A. T., and Filho, J. A. F. D. (1999a). Impact of wildfires on the megafauna of Emas National Park, central Brazil. Oryx 33, 108. doi:10.1017/ s0030605300030362

Silveira, L., Rodrigues, F. H. G., De Jacorno, A. T. A., and Diniz, J. A. F. (1999b). Impact of wildfires on the megafauna of Emas National Park, central Brazil. ORYX. doi:10.1046/j.1365-3008.1999.00039.x

Simons, L. H. (1991). Rodent Dynamics in Relation to Fire in the Sonoran Desert. Journal of Mammalogy. doi: $10.2307 / 1382135$

Simons, L. H. (1989). Vertebrates Killed by Desert Fire. The Southwestern Naturalist. doi:10.2307/3671821

Sims, H. P., and Buckner, C. H. (1973). The Effect of Clear Cutting and Burning of Pinus banksiana Forests on the Populations of Small Mammals in Southeastern Manitoba. American Midland Naturalist. doi: $10.2307 / 2424288$

Sinsch, U. (1990). Migration and orientation in anuran amphibians. Ethology Ecology and Evolution. doi:10. 1080/08927014.1990.9525494

Smith, J. K., and Lyon, L. J. (2000). "Wildlan fire in ecosystems:effect of fire on fauna." (US Department of Agriculture, Forest Service, Rocky Mountain Research Station.)

Stawski, C., Körtner, G., Nowack, J., and Geiser, F. (2015a). The importance of mammalian torpor for survival in a post-fire landscape. Biology Letters. doi:10.1098/rsbl.2015.0134

Stawski, C., Matthews, J. K., Körtner, G., and Geiser, F. (2015b). Physiological and behavioural responses of a 
small heterothermic mammal to fire stimuli. Physiology and Behavior. doi:10.1016/j.physbeh.2015.09.002

Sunquist, M. E. (1967). Effects of Fire on Raccoon Behavior. Journal of Mammalogy. doi:10.2307/1377606

Sutherland, E. F., and Dickman, C. R. (1999a). Mechanisms of recovery after fire by rodents in the Australian environment: A review. Wildlife Research 26, 405-419. doi:10.1071/WR97045

Sutherland, E. F., and Dickman, C. R. (1999b). Mechanisms of recovery after fire by rodents in the Australian environment: A review. Wildlife Research. doi:10.1071/WR97045

Taggart, D. A., Schultz, D. J., Corrigan, T. C., Schultz, T. J., Stevens, M., Panther, D., and White, C. R. (2015). Reintroduction methods and a review of mortality in the brush-tailed rock-wallaby, Grampians National Park, Australia. Australian Journal of Zoology. doi:10.1071/ZO15029

Taylor, G., Canessa, S., Clarke, R. H., Ingwersen, D., Armstrong, D. P., Seddon, P. J., and Ewen, J. G. (2017). Is Reintroduction Biology an Effective Applied Science? Trends in Ecology and Evolution. doi:10.1016/j.tree.2017.08.002

Tetzlaff, S. J., Sperry, J. H., and DeGregorio, B. A. (2019). Effects of antipredator training, environmental enrichment, and soft release on wildlife translocations: A review and meta-analysis. Biological Conservation. doi:10.1016/j.biocon.2019.05.054

Thompson, P., and Fox, B. J. (1993). Asymmetric Competition in Australian Heathland Rodents: A Reciprocal Removal Experiment Demonstrating the Influence of Size-Class Structure. Oikos. doi:10.2307/3545471

Turco, M., Jerez, S., Augusto, S., Tarín-Carrasco, P., Ratola, N., Jiménez-Guerrero, P., and Trigo, R. M. (2019). Climate drivers of the 2017 devastating fires in Portugal. Scientific Reports. doi:10.1038/s41598-01950281-2

Turner, M. G. (2010). Disturbance and landscape dynamics in a changing world. Ecology. doi:10.1890/100097.1

Ulrich, R. S. (1984). View through a window may influence recovery from surgery. Science. doi:10.1126/ science. 6143402

Vacanti, P. L., and Geluso, K. N. (1985). Recolonization of a burned prairie by meadow voles Microtus pennsylvanicus. Prairie Naturalist.

Valentine, L. E., Fisher, R., Wilson, B. A., Sonneman, T., Stock, W. D., Fleming, P. A., and Hobbs, R. J. (2014). Time since fire influences food resources for an endangered species, Carnaby's cockatoo, in a fire-prone landscape. Biological Conservation. doi:10.1016/j. biocon.2014.04.006
Valentine, L. E., Schwarzkopf, L., and Johnson, C. N. (2012). Effects of a short fire-return interval on resources and assemblage structure of birds in a tropical savanna. Austral Ecology. doi:10.1111/j.14429993.2011.02244.x

Vernes, K. (2000). Immediate effects of fire on survivorship of the northern bettong (Bettongia tropica): An endangered Australian marsupial. Biological Conservation. doi:10.1016/S0006-3207(00)00086-0

Villard, P. (1994). Foraging behavior of black-backed and three-toed woodpeckers during spring and summer in a Canadian boreal forest. Canadian Journal of Zoology. doi:10.1139/z94-266

Vlug, H., and Borden, J. H. (1973). Soil Acari and Collembola Populations Affected by Logging and Slash Burning in a Coastal British Columbia Coniferous Forest 1. Environmental Entomology. doi:10.1093/ ee/2.6.1016

Vogl, R. J. (1973). Effects of Fire on the Plants and Animals of a Florida Wetland. American Midland Naturalist. doi:10.2307/2424038

Wachob, D. G. (1996). A microclimate analysis of nestsite selection by mountain chickadees. Journal of Field Ornithology.

Weinstein, S. B., Buck, J. C., and Young, H. S. (2018). A landscape of disgust. Science. doi:10.1126/science. aas 8694

Westerling, A. L. R. (2016). Increasing western US forest wildfire activity: Sensitivity to changes in the timing of spring. Philosophical Transactions of the Royal Society B: Biological Sciences. doi:10.1098/ rstb.2015.0178

Whelan, R. J. (1995). “The Ecology of Fire.” (Cambridge University Press.)

Whelan, R. J., Rodgerson, L., Dickman, C. R., and Sutherland, E. F. (2002). Critical life processes of plants and animals: developing a process-based understanding of population changes in fire-prone landscapes. In "Flammable Australia: the fire regimes and biodiversity of a continent." (Ed M. A. Bradstock, R. A.; Williams, J. E. \& Gills.) pp. 94-124. (Cambridge.)

White, J. I. (2014). Supporting the information management needs of people helping animals in disasters. Proceedings of the International ACM SIGGROUP Conference on Supporting Group Work, 278-280. doi:10.1145/2660398.2660441

Wiebe, K. L. (2001). Microclimate of Tree Cavity Nests: Is it Important for Reproductive Success in Northern Flickers? The Auk. doi:10.1093/auk/118.2.412

Williams, N. M., Crone, E. E., Roulston, T. H., Minckley, R. L., Packer, L., and Potts, S. G. (2010). Ecological and life-history traits predict bee species responses 
to environmental disturbances. Biological Conservation. doi:10.1016/j.biocon.2010.03.024

Wintle, B. A., Legge, S., and Woinarski, J. C. Z. (2020). After the Megafires: What Next for Australian Wildlife? Trends in Ecology and Evolution. doi:10.1016/j. tree.2020.06.009

Xing, S., Wang, X., Diao, H., Zhang, M., Zhou, Y., and Feng, J. (2019). Changes in the cecal microbiota of laying hens during heat stress is mainly associated with reduced feed intake. Poultry science. doi: $10.3382 / \mathrm{ps} / \mathrm{pez} 440$

Yell, S. (2010). "Breakfast is now tea, toast and tissues": Affectand the media coverage ofbushfires. Media International Australia. doi:10.1177/1329878x1013700113
Yoder, J. (2004). Playing with fire: Endogenous risk in resource management. American Journal of Agricultural Economics. doi:10.1111/j.0002-9092.2004.00644.x Zamboni, T., Di Martino, S., and Jiménez-Pérez, I. (2017). A review of a multispecies reintroduction to restore a large ecosystem: The Iberá Rewilding Program (Argentina). Perspectives in Ecology and Conservation. doi:10.1016/j.pecon.2017.10.001

Zouaoui, S., Boudreault, C., Drapeau, P., and Bergeron, Y. (2014). Influence of time since fire and micro-habitat availability on terricolous lichen communities in black spruce (Picea mariana) boreal forests. Forests. doi:10.3390/f5112793 